\title{
単層ラチスドームを対象とした地震荷重と耐震性能評価法の提案 SEISMIC LOADS FOR SINGLE LAYER RETICULAR DOMES AND SEISMIC PERFORMANCE EVALUATION
}

\author{
中澤祥二*，柳澤利 昌 ${ }^{* *}$, 加藤史郎*** \\ Shoji NAKAZAWA, Toshimasa YANAGISAWA and Shiro KATO
}

\begin{abstract}
The present research proposes statically equivalent seismic loads and a method to evaluate seismic performance which can be applied to design of single layer reticular domes. The dome is supported by pins at its circular periphery. First, the responses of accelerations and axial forces are evaluated by linear elastic response analysis for the serviceability limit level, and based on the results the magnitudes and distributions of the seismic loads to the dome surface are proposed for their effect of the dynamic responses. Second, the accuracy of the proposed seismic loads are investigated by comparing the axial forces of members under the seismic loads with those obtained by linear elastic response analysis using many simulated design earthquake motions. Third, the collapse mechanism is discussed based on pushover analysis using the proposed seismic loads but with increased magnitudes for various seismic intensities, followed by comparison of the results with those of elastic-plastic dynamic buckling analysis for severe earthquake motions. Finally, the dynamic ductility indexes of the domes are calculated and an effective evaluation method of their seismic performance of the domes is proposed.
\end{abstract}

Keywords : Single layer reticular dome, Response analysis, Seismic load, Dynamic ductility index, seismic performance 単層ラチスドーム，地震応答解析，地震荷重，動的勒性指標，而震性能

\section{1. 序論}

ドームなどの空間構造の耐力は座屈により決まるため, 既往の研 究 1)では固定荷重や積雪荷重に対する耐力やその推定方法が議論さ れてきた。一方，日本や中国のように地震の多い地域では地震荷重 も考慮して耐震性能を評価寸る必要がある. しかし, この種の構造 の応答性状は重層構造とは異なるため, 現行の基準をそのまま適用 することはできない，したがって，設計時には，地震応答解析から 地震時の応力を評価し, 弾性設計することが一般的となっている.

ドームを対象とした応答性状に関する研究は比較的多い。たとえ ば，文献 2)では複層ドームを対象とした上下振動に対する検討を行 い，崩壊加速度および安全率（余裕度）を検討している. また，文 献 3)では網目形状やドームの半開角を考慮し, 静的耐力および動的 耐力の評価を行っている. 文献 4，5)では単層の高・低ライズドー ムを対象とし, 地震応答解析から地震荷重を作成し, 崩壊加速度に ついて検討している．文献 6)では崩壊性状を検討するとともに，構 造物全体の変形と部材の損傷を評価している。 また，文献 7)では弾 塑性地震応答解析に基づいて, 部材の限界変形に応じた耐震性能を 評価している。しかし，地震応答解析は，時間が掛るほかに，地震 波の特性に大きく依存するため, 分析がやや困難である. そのため, 静的解析から地震時の応力や耐震性能を評価寸る手法が望まれる.

静的解析から地震時の応答を検討する際は, 地震荷重を設定する 必要がある. ドームを対象とした地震荷重に関する研究は文献 8)な どにまとめられている. 文献 9,10)では励起振動モードを並列した
多質点モデルによる応答評価を行い，文献 11，12)では複層ドーム を対象として固有振動解析から主要となるモードを 2 つ採用して地 震荷重を作成している，また，簡便にドームの地震荷重を作成する ために, 文献 13)では加速度分布を $\sin$ 分布や $\cos$ 分布で仮定し, 文 献 14)でその地震荷重のデプス/スパン比 $1 / 100$ 程度以下のドームへ の適用性を分析している.しかし，これらの研究は上部構造（ドー ム）を弾性とした場合の検討に留まり，ドームの初期降伏時の耐力 や耐震性能の評価までは十分に議論されていない. 本研究の前半では, 円形平面の単層ラチスドーム (以下, ドーム) を対象とした地震荷重を提案し，その妥当性を検討する。ドームは ブレースなどで構成された下部構造に支持されることが殆どである が，本研究ではドームの地震荷重を簡易な式で表現する研究の第一 段階として下部構造は設けず，支持条件はピン支持とする．まず， 固有振動解析および時刻歴地震応答解析を実施し, ドームの応答特 性を把握する．次に，時刻歴地震応答解析から得られる軸力分布を 分析し，分析結果に基づき地震荷重に使用する加速度分布を提案す るとともに，軸力およびドーム最下層の層せん断力を模擬できる地 震荷重を提案する. その後, その地震荷重を用いた静的解析と応答 解析結果を比較し, 地震荷重の精度と妥当性を確認する.後半では, 弾塑性地震応答解析とプッシュオーバー解析（以後, PO 解析と呼 ぶ）の結果からドームの耐荷性能を検討し, 提案した地震荷重の適 用性を検討する。ささらに，文献 7) と同様に，限界変形に応じた動的 勒性指標を算出し，これを用いてドームの耐震性能を評価する.

\footnotetext{
* 豊橋技術科学大学建築・都市システム学系 教授・博士 (工学)

** 豊橋技術科学大学建築・都市システム学専攻 大学院生

*** 豊橋技術科学大学 名誉教授. 工博
}

Prof., Dept. of Arch. and Civil Eng., Toyohashi Univ. of Tech., Dr. Eng.

Graduate Student, Dept. of Arch. and Civil Eng., Toyohashi Univ. of Tech. Prof. Emeritus, Toyohashi Univ. of Tech., Dr. Eng. 


\section{2. 解析モデル}

\section{1 概要}

本研究では図 1 に示寸円形平面のパラレルラメラドームを対象と する. 研究の第一段階として, 下部構造は設けず，剛性の高い下部 構造に直接に支持される場合を想定し, 屋根周辺をピン支持とする. また, 曲率半径 $R$, ライズ $H$, 円弧長さ $B$ を表 1 に示す. 本研究で は固定荷重時の安全率を 2 程度として設計しているため, 重量の変 化とともにドーム部材の断面も変化するが，ドームの固有周期や振 動性状は大きく変化しない. そこで, ドームの規模に関係なく単位 重量 $w_{d}$ は $1.5 \mathrm{kN} / \mathrm{m}^{2}$ とする. なお, 支配面積に応じて各節点に重量 を分配する. 部材は全て等断面, 部材は節点で剛接合とする. また, 全体座屈に焦点を当てるため, 1 部材 1 要素としてモデル化する.

本研究ではスパン $L$, ドームの半開角 $\phi_{0}$ および部材細長比 $\lambda_{0}$ をパ ラメータとし， $L$ は $60 \mathrm{~m}, 80 \mathrm{~m}, 100 \mathrm{~m}, 120 \mathrm{~m}$ の 4 種類, $\phi_{0}$ は $20^{\circ}$, $30^{\circ}, 40^{\circ}, 50^{\circ}$ の 4 種類, $\lambda_{0}$ は $40,50,60,70,80$ の 5 種類とする. また, $\mathrm{AO}$ 線上の稜線の分割数 $n$ は表 2 に示すように, $n=10$ とした 場合とメッシュの粗さを同じとした場合, つまり $L=60 \mathrm{~m}$ では $n=6$, $L=80 \mathrm{~m}$ では $n=8, L=120 \mathrm{~m}$ では $n=12$ について検討する．なお，ドー 厶頂部（O 点）を第 0 周とし，テンションリングを第 $n$ 周とする.

部材モデルとして, 弾性梁と両端に部材降伏を表現する剛塑性七 ンジから構成される両端ばね梁モデルを採用する．弾性梁は座屈た わみ角法で定式化しており個材の弾性座屈を考慮できるが, 部材中 央で塑性ヒンジが入るような座屈挙動を考慮できない. 部材モデル の詳細は文献 15)に示されているため, 本論では省略する.

\section{2 部材断面の設定方法}

ドーム部材は SN400 の鋼管を想定し, ヤング係数 $E_{s}$ は $205000 \mathrm{~N} / \mathrm{mm}^{2}$, 降伏応力度 $\sigma_{y}$ は $235 \mathrm{~N} / \mathrm{mm}^{2}$ とする. 部材管径（管厚 中心の直径） $d_{0}$ は次式で与える.

$$
d_{0}=2 \sqrt{2} \cdot \ell_{0} / \lambda_{0}
$$

ここで, $\ell_{0}$ は稜線材の長さを表す. 部材断面積 $A$, 断面二次モーメ

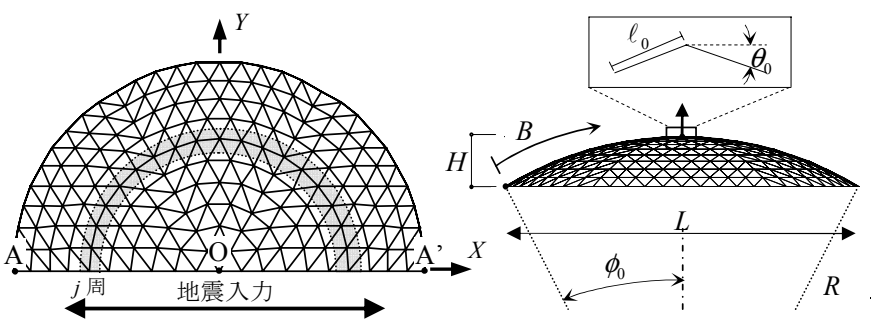

図 1 解析モデル $(n=10)$

表 1 幾何学的形状

\begin{tabular}{c|cccc|cccc}
\hline$L[\mathrm{~m}]$ & \multicolumn{5}{|c|}{60} & \multicolumn{5}{c}{80} \\
\hline$\phi_{0}\left[^{\circ}\right]$ & 20 & 30 & 40 & 50 & 20 & 30 & 40 & 50 \\
\hline$R[\mathrm{~m}]$ & 87.71 & 60.00 & 46.67 & 39.16 & 116.95 & 80.00 & 62.23 & 52.22 \\
$H[\mathrm{~m}]$ & 5.29 & 8.04 & 10.92 & 13.99 & 7.05 & 10.72 & 14.56 & 18.65 \\
$B[\mathrm{~m}]$ & 61.24 & 62.83 & 65.17 & 68.35 & 81.65 & 83.78 & 86.89 & 91.13 \\
\hline \hline$L[\mathrm{~m}]$ & \multicolumn{6}{|c|}{100} & & \multicolumn{5}{c}{120} \\
\hline$\phi_{0}\left[^{\circ}\right]$ & 20 & 30 & 40 & 50 & 20 & 30 & 40 & 50 \\
\hline$R[\mathrm{~m}]$ & 146.19 & 100.00 & 77.79 & 65.27 & 175.43 & 120.00 & 93.34 & 78.32 \\
$H[\mathrm{~m}]$ & 8.82 & 13.40 & 18.20 & 23.32 & 10.58 & 16.08 & 21.84 & 27.98 \\
$B[\mathrm{~m}]$ & 102.06 & 104.72 & 108.61 & 113.92 & 122.47 & 125.66 & 130.33 & 136.70 \\
\hline
\end{tabular}

表 2 ドームのパラメータ $\xi_{0}$

\begin{tabular}{c|c|cccc}
\hline$L[\mathrm{~m}]$ & $n$ & $\phi_{0}=20^{\circ}$ & $\phi_{0}=30^{\circ}$ & $\phi_{0}=40^{\circ}$ & $\phi_{0}=50^{\circ}$ \\
\hline $60-120$ & 10 & $12.2-24.3$ & $8.1-16.2$ & $6.1-12.2$ & $4.9-9.7$ \\
60 & 6 & $7.3-14.6$ & $4.9-9.7$ & $3.7-7.3$ & $2.9-5.8$ \\
80 & 8 & $9.7-19.5$ & $6.5-13.0$ & $4.9-9.7$ & $3.9-7.8$ \\
120 & 12 & $14.6-29.2$ & $9.7-19.5$ & $7.3-14.6$ & $5.8-11.7$ \\
\hline
\end{tabular}

ント $I$, 断面二次半径 $r_{g}$, 断面係数 $Z_{e}$, 降伏軸力 $N_{y}$, 全塑性モーメ ント $M_{p}$ の近似值は次式で与える.

$$
\begin{aligned}
& A=\pi \cdot d_{0} \cdot t, I=(\pi / 8) \cdot d_{0}^{3} \cdot t, r_{g}=\ell_{0} / \lambda_{0}, Z_{e}=I /\left(d_{0} / 2\right) \\
& N_{y}=A \cdot \sigma_{y}, M_{p}=d_{0}{ }^{2} \cdot t \cdot \sigma_{y}
\end{aligned}
$$

ここで， $t$ は部材管厚を表す．固定荷重に対するドームの座屈荷重 $P_{c r}$ は修正ダンカレー式 ${ }^{1)} よ り$ 近似的に算出する

$$
\lambda_{s}^{2}\left(\frac{P_{c r}}{P^{p l}}\right)+\left(\frac{P_{c r}}{P^{p l}}\right)^{2}=1 \quad ; \quad P_{c r}=\frac{2}{\sqrt{\lambda_{s}^{4}+4}+\lambda_{s}^{2}} \cdot P^{p l}
$$

ここで, $P_{c r}^{e l}$ は弾性座屈荷重, $P^{p l}$ は塑性耐力, $\lambda_{s}$ は正規化細長比を 表し，次式 ${ }^{1)}$ で与えられる.

$$
\begin{aligned}
& \lambda_{s}=\sqrt{\frac{P^{p l}}{P_{c r}^{e l}}}=\sqrt{\frac{6 \cdot N_{y} \cdot \theta_{0} \cdot \gamma_{m}}{\alpha_{0}\left(\xi_{0}\right) \cdot \beta(\kappa) \cdot E_{s} \cdot A \cdot \theta_{0}^{3} \cdot \xi_{0}}} \\
& P_{c r}^{e l}\left(\xi_{0}, \kappa\right)=\alpha_{0}\left(\xi_{0}\right) \cdot \beta(\kappa) \cdot E_{s} \cdot A \cdot \theta_{0}{ }^{3} \cdot \xi_{0} \quad: \quad \beta(\kappa)=1.0 \\
& P^{p l}=6 \cdot N_{y} \cdot \theta_{0} \cdot \gamma_{m}: \gamma_{m}=0.7
\end{aligned}
$$

ここで， $\theta_{0}$ は部材半開角（単位は $\left.\mathrm{rad}\right), \quad \beta(\kappa)$ は材端の曲げ剛性によ る座屈荷重低減を表す，なお，剛接合としているので， $\beta(\kappa)=1.0$ と する. $\xi_{0}$ はドームの無次元化パラメータを表し, 次式で与えられる.

$$
\xi_{0}=12 \sqrt{2} /\left(\lambda_{0} \theta_{0}\right)
$$

対象構造物の $\xi_{0}$ を表 2 にまとめる. 表 2 より，分割数 $n=10$ のモデ ルは $\xi_{0}=4.9$ 以上であり, 個材座屈が発生する可能性は低いと考えら れる ${ }^{1)}$. しかし, $n=6,8$ では $\xi_{0}$ がやや小さいモデルも存在するため, 非線形解析を実施する際は注意する必要がある. $\alpha_{0}\left(\xi_{0}\right)$ は弾性座屈荷 重低減係数を表し，本研究では $0.5^{1)}$ と仮定する.

部材管厚 $t$ は次式で与えられる.

$$
t=v_{s} \cdot t_{0} \cdot P_{0} / P_{c r}
$$

ここで， $v_{s}$ は安全率 $(=2.0) ， t_{0}$ は初期管厚， $P_{0}$ は 1 節点当たりの基 本荷重を表す。 $P_{c r}$ は, 初期管厚 $t_{0}$ に対応して求めた $P^{p l}$ と式(3)から 計算する，なお，本研究では $d_{0}$ を一定とし， $t$ を変化させて断面算 定し， $0.5 \mathrm{~mm}$ 刻みで設定する。設定した管厚を表 3 に示す。なお， 本節では主に全体座屈が起きる形状を対象としており，個材座屈が 主となる場合は，別の研究が必要である。

\section{3. 入力地震動}

入力水平地震動の周波数特性の平均值として国土交通省告示 ${ }^{16)}$ に 示される加速度応答スペクトル $S_{a d 0}$ を採用する.

$$
S_{a d 0}(T, h)=S_{a 0}(T) \times F_{h}(h) \times G_{s}(T)
$$

\begin{tabular}{c|c|cc|cc|c|cc}
\hline & & \multicolumn{2}{|c|}{$L=60 \mathrm{~m}$} & \multicolumn{2}{c|}{$L=80 \mathrm{~m}$} & $L=100 \mathrm{~m}$ & \multicolumn{2}{c}{$L=120 \mathrm{~m}$} \\
\hline$\phi_{0}\left[^{\circ}\right]$ & $\lambda_{0}$ & $n=10$ & $n=6$ & $n=10$ & $n=8$ & $n=10$ & $n=10$ & $n=12$ \\
\hline \multirow{4}{*}{20} & 40 & 0.40 & 0.35 & 0.55 & 0.50 & 0.65 & 0.80 & 0.90 \\
& 50 & 0.55 & 0.45 & 0.75 & 0.65 & 0.95 & 1.10 & 1.25 \\
& 60 & 0.75 & 0.55 & 1.00 & 0.90 & 1.25 & 1.50 & 1.70 \\
& 70 & 1.00 & 0.70 & 1.30 & 1.10 & 1.65 & 1.95 & 2.25 \\
& 80 & 1.25 & 0.90 & 1.65 & 1.40 & 2.05 & 2.45 & 2.85 \\
\hline \multirow{5}{*}{30} & 40 & 0.25 & 0.20 & 0.30 & 0.30 & 0.40 & 0.45 & 0.50 \\
& 50 & 0.30 & 0.25 & 0.40 & 0.40 & 0.50 & 0.60 & 0.70 \\
& 60 & 0.40 & 0.35 & 0.55 & 0.50 & 0.70 & 0.80 & 0.90 \\
& 70 & 0.55 & 0.40 & 0.70 & 0.60 & 0.85 & 1.05 & 1.15 \\
& 80 & 0.65 & 0.50 & 0.85 & 0.75 & 1.05 & 1.25 & 1.45 \\
\hline \multirow{5}{*}{40} & 40 & 0.20 & 0.15 & 0.25 & 0.20 & 0.30 & 0.35 & 0.35 \\
& 50 & 0.25 & 0.20 & 0.30 & 0.30 & 0.35 & 0.45 & 0.45 \\
& 60 & 0.30 & 0.25 & 0.40 & 0.35 & 0.45 & 0.55 & 0.60 \\
& 70 & 0.35 & 0.30 & 0.45 & 0.45 & 0.60 & 0.70 & 0.75 \\
& 80 & 0.45 & 0.35 & 0.55 & 0.50 & 0.70 & 0.85 & 0.95 \\
\hline \multirow{5}{*}{50} & 40 & 0.15 & 0.15 & 0.20 & 0.20 & 0.20 & 0.25 & 0.30 \\
& 50 & 0.20 & 0.15 & 0.25 & 0.20 & 0.30 & 0.35 & 0.35 \\
& 60 & 0.25 & 0.20 & 0.30 & 0.30 & 0.35 & 0.45 & 0.45 \\
& 70 & 0.30 & 0.25 & 0.35 & 0.35 & 0.45 & 0.55 & 0.55 \\
& 80 & 0.35 & 0.30 & 0.45 & 0.40 & 0.55 & 0.65 & 0.70 \\
\hline
\end{tabular}




$$
S_{a d}\left(\lambda_{E}, T, h\right)=\lambda_{E} \times S_{a d 0}(T, h)
$$

なお， $S_{a d 0}$ および $S_{a 0}$ は減衰定数 $h$ が $5 \%$ の損傷限界レベルの地表お よび工学的基盤における加速度応答スペクトルを表す． $F_{h}$ は $h$ によ る応答スペクトルの低減率を表す. 表層地盤による増幅係数 $G_{s}$ は第 2 種の地盤を想定し, 簡易法による増幅係数 ${ }^{17)}$ を採用する. 地震動 の大きさは地震動強さ $\lambda_{E}$ で表し, 国土交通省告示の損傷限界の地震 動を $\lambda_{E}=1.0$, 安全限界の地震動を $\lambda_{E}=5.0$ とする. また, $\lambda_{\mathrm{E}}=1.0$ に対 する入力の振幅值（最大地動加速度）を $A_{\max }$ とする.

地震応答解析に用いる模擬地震波は観測波の位相特性を用い，減 衰定数 $5 \%$ の加速度応答スペクトルに適合するように作成する。ま た, 入力地震動の位相特性による最大応答のばらつきを検討するた め, 文献 18)で作成した 12 波の模擬地震動を用いる. なお, 入力方 向は水平方向 $(X$ 方向）のみとする.

\section{4. 単層ラチスドームの特徵}

\section{1 固定荷重時の静的解析}

2.2 節で断面を設定したドームの固定荷重に対する耐力を検討す る. なお, 前述のように全体座屈に焦点を当てる. 例として, スパ ン $L=100 \mathrm{~m}$, 半開角 $\phi_{0}=30^{\circ}$, 部材細長比 $\lambda_{0}=50$ のモデルの荷重変位 関係を図 2 に示す。なお，最大鉛直变位がスパンの $1 / 300$ に達した 時の節点を注目節点とする. 図中の $\lambda$ は荷重倍率，実線は初期不整 なし（完全形状）の結果, 破線は初期不整ありの結果を示す. 初期 不整は線形座屈解析（固有值解析）よる 1 次モード比例とし, 最大 不整量は等価シェル厚 $t_{e q}$ の $20 \%$ とする $\left(t_{e q}\right.$ の定義は次節で説明する). なお，本モデルの線形座屈と弾性座屈（初期不整あり）の荷重倍率 は, 6.02 と 3.01 である. 図 2 より, 完全形状と初期不整ありのモデ ルの耐力（弾塑性座屈荷重）の荷重倍率は 2.91 と 2.29 であり, 固 定荷重の 2 倍程度の耐力が確保できている. 全モデルの耐力を図 3 に示す. 図中の破線は全モデルの平均值で 2.6, 一点鎖線は平均值 標準偏差で 2.3〜2.9 となり, 耐力の倍率は全て 2 倍以上となる.

\section{2 固有振動解析}

(a) 固有周期, 振動モード

固有振動解析より得られる弾性時の固有周期 $T_{i}$ およびエネルギー
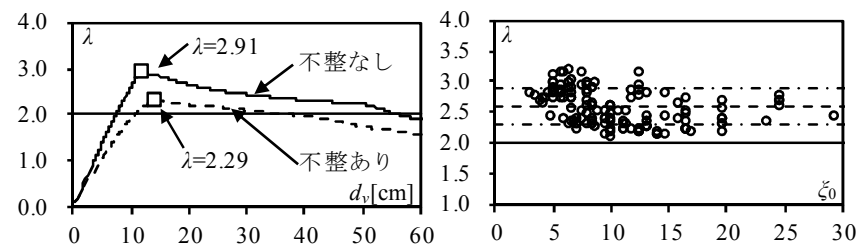

図 2 荷重変位関係 (固定荷重)
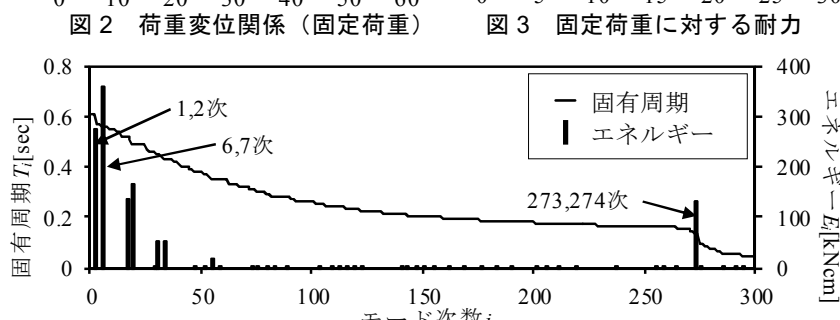

図 4 固有周期とエネルギー $\left(L=100 \mathrm{~m}, \phi_{0}=30^{\circ}, \lambda_{0}=50\right)$

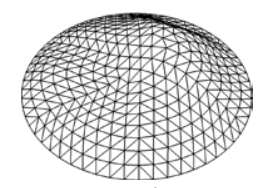

(a) 1,2 次 図 5

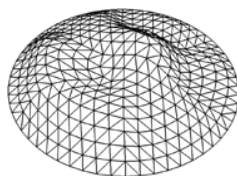

(b) 6,7 次 固有振動モード $(L=100 \mathrm{~m}$,

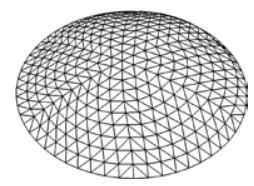

(c) 273,274 次 $\phi_{0}=30^{\circ}, \lambda_{0}=50$ )
$E_{i}$ を図 4 に示す。図中のエネルギー $E_{i}$ は次式で与えられる

$$
E_{i}=0.5 \cdot \rho_{i} \cdot m \cdot S_{v}\left(T_{i}, h\right)^{2}
$$

ここで, $\rho_{i}$ は有効質量比, $m$ は総質量 $(=W / g), g$ は重力加速度, $S_{v}\left(T_{i}, h\right)$ は速度スペクトル $\left(=S_{a d 0}\left(T_{i}, h\right) /\left(2 \pi / T_{i}\right)\right), i$ はモード次数を表す. なお, $h$ は $2 \%$ とする. また，振動モードを図 5 に示す. 図 4 より，対象と するドームの 1 次固有周期は $0.6 \mathrm{sec}$ 程度となる. 本論では結果を図 示しないが，その他のモデルも 1 次固有周期は $0.4 \sim 0.7 \mathrm{sec}$ となり， 短周期で振動する。したがって, 対象ドームの 1 次固有周期は加速 度スペクトル一定領域に位置する。また，ドームでは多くのモード が発生し, その数は部材細長比 $\lambda_{0}$ や分割数 $n$ によって変化する. こ れらのモードの固有周期は近接し， 1 次モードと同様にスペクトル 一定領域に位置する。また, 図 5 より，低次では面外に変形するモ 一ドが発生し，モード次数に伴って波数が増加する. なお，この傾 向は文献 9，10)でも確認され，振動モードが応答に寄与する影響に ついても分析されている。しかし, 図 5(c)より, 高次では面内に変 形するモードも発生する。文献 11，12)ではドームの主要な 2 個の モードで地震荷重を設定しているが，上記の理由から単層ラチスド 一ムでは 2 個程度のモードから地震荷重を設定することは困難であ ると考えられる。したがって，以下に示すように，別の視点から地 震荷重を設定する.

(b) 1 次固有周期の推定

本研究では文献 19)に示される無次元固有円振動数 $\Omega_{0}$ を用いて対 象ドームの 1 次固有周期を簡易に推定する方法を提案する. 偏平シ エルの無次元固有円振動数 $\Omega_{0}$ は次式で与えられる.

$$
\Omega_{0}=\omega_{0} / \sqrt{\left(E_{e q} t_{e q}\right) /\left\{\left(1-v^{2}\right) \rho a b\right\}} ; a=b=\sqrt{\pi} \cdot\left(R \sin \phi_{0}\right)
$$

ここで, $\rho$ は単位面積あたりの質量 $\left(=w_{d} / g\right), v$ はポアソン比 $(=1 / 3)$, $R$ はドームの曲率半径を表す. 文献 19)では矩形平面を対象としてい るが，本研究では式(12)のように $a$ と $b$ を設定し，面積を等価にし ている. $\omega_{0}$ は固有円振動数を表し, 本研究では固有振動解析から得 られる 1 次モードの結果を用いる. $E_{\text {eq }}$ は等価ヤング係数, $t_{e q}$ は等価 シェル厚を表し，次式で与えられる.

$$
E_{e q}=E_{s} A /\left(3 \ell_{0} r_{g}\right) \quad, \quad t_{e q}=2 \sqrt{3} \cdot r_{g}
$$

ここで, $r_{g}$ はドーム部材の断面二次半径を表す. 式(13)を式(12)に代 入すると, 次式が得られる.

$$
\Omega_{0}=\omega_{0} \cdot \sqrt{\rho \cdot \pi \cdot\left(R \sin \phi_{0}\right)^{2} /\left\{(3 \sqrt{3} / 4) \cdot\left(E_{s} \cdot A / \ell_{0}\right)\right\}}
$$

なお，式(13)は三角形網目のドームを対象としたものであるため， 網目形状が変化する際は別の式を用いる必要がある.

固有振動解析による $\omega_{0}$ を用いて算出した $\Omega_{0}$ とドームの半開角 $\phi_{0}$ の関係を図 6 に示す (全モデル). 図 6(b)中の $r$ は $a$ と曲率半径 $R$ の 比率 $(r=a / R)$ を表す. 図 6 より, 本研究で対象とした範囲では, $\Omega_{0}$ は $\phi_{0}$ に伴って増加する傾向がある. $\Omega_{0}$ は $R / t_{e q}$ にやや依存するが, その影響は非常に小さい. また, $\Omega_{0}$ を $\phi_{0}$ の関数として表現できると 考えられる.そこで, 本研究では $\Omega_{0}$ の近似值として次式を提案寸る.

$$
\Omega_{0(a)}=0.625 \sqrt{\phi_{0}} /\left(1-1.064 \phi_{0}+0.650 \phi_{0}^{2}\right)
$$

式(15)の值を図 6(a)に実線で示す．図 6(a)より，式(15)の值は解析結 果と良い対応を示し, 式(15)によれば, 固有振動解析を行わずにド 一ムの 1 次固有周期を簡易に算出することができる。参考として, 文献 7，20)で対象としたドームの無次元固有円振動数 $\Omega_{0}$ を図 6(a) 中にそれぞれ口，৩として示す。これより，式(15)の值と概ね対応 
し, 本結果の一般性が確認できる. なお, 図 6 の結果は支持条件に 影響されるため, 下部構造を考慮した場合については今後, 議論の 予定である.

\section{3 曲げモーメントの影響}

本節では, 地震応答解析から得られる軸応力と曲げ応力を比較す る. $\mathrm{AOA}^{\prime}$ 線上付近のフープ材と稯線材に生じる軸応力 $\sigma_{N}$ と曲げ応 力 $\sigma_{M}$ の比較を図 7,8 に示寸. $\sigma_{N}$ と $\sigma_{M}$ は次式で与えられる.

$$
\sigma_{N}=|N / A| \quad, \quad \sigma_{M}=\sqrt{\left(M_{y} / Z_{e}\right)^{2}+\left(M_{z} / Z_{e}\right)^{2}}
$$

ここで, $Z_{e}$ は断面係数を表す. 図中のプロットは 12 波の結果を表す. 本節では荷重として, (1)固定荷重+地震荷重 $\left(\lambda_{E}=1.0\right)$, (2)固定荷重+ 地震荷重 $\left(\lambda_{E}=2.5\right)$ の 2 種類を設定する. なお, 本研究で対象とす るドームはフープ材で最初に塑性ヒンジが発生する.

図 7 より, フープ材は曲げ応力に比べて軸応力が大きく, 地震動 強さ $\lambda_{E}$ が 2.5 に達してもその関係は変わらない. 図 8 より, 稜線材 の多くは軸力が支配的となるが, 曲げ応力が大きくなる部材も存在 する. しかし, 曲げ応力が大きくなる部材に生じる軸応力は比較的 小さくなり，地震動に対するドームの耐力に大きく影響しないと考 えられる.したがって,ドーム部材の軸力を精度よく推定できれば, 地震時のドームの耐力を精度よく評価できると考えられる。

\section{4 層せん断力係数}

地震応答解析から得られるドーム最下層の最大層せん断力係数 $C_{0 d}$ を半開角 $\phi_{0}$ ごとに図 9 に示す. 図中のプロット $(\bigcirc, \square, \diamond$,

$\triangle)$ はスパン $L$, 部材細長比 $\lambda_{0}$ および分割数 $n$ の違いも含めた全モ デルの結果（12 波の地震動ごとの結果を含む）を表す．実線はそれ らの平均值, 破線は平均值+標準偏差, 一点鎖線は平均值 $+2 \times$ 標準偏 差を表す. なお, 本結果は地震動強さ $\lambda_{E}$ を 1.0 としたものである. 図 9 より, 最大層せん断力係数 $C_{0 d}$ はスパン $L$ に僅かに依存するが, その影響は小さく, 平均值に注目すると, 最大層せん断力係数 $C_{0 d}$ は $0.17 \sim 0.20$ 程度となる. また, 変動係数は $10 \%$ 程度でばらつきは 大きくないが，断面算定等に用いる場合は平均值+標準偏差や平均 值 $+2 \times$ 標準偏差の值を勘案し， 0.21 や 0.23 程度の值を用いることも 考えられる. なお，この值はばらつきを考慮しても 1 次固有周期に 対応する告示の絶対応答加速度スペクトルより低い值となる. これ は, 複数励起される主要な振動モードの有効質量比が小さいためで ある. したがって, 設計時に用いるドーム最下層の層せん断力を評 価する際は，この性状を考慮する必要がある.

\section{5. 地震荷重の提案}

\section{1 提案式}

以下では地震応答解析の結果を参考に, ドーム部材（フープ材と 稜線材）の最大軸力およびドーム最下層の最大層せん断力を模擬で きる地震荷重を提案する. なお，提案式は地震応答解析より得られ る 12 波の入力地震動による応答の平均值に対応するように作成し, 入力地震動の違いによる応答のばらつきは, 後述する地震荷重の精 度のところで議論する. また, フープ材は図 1 に示寸 AOA'線に近 接する部材，稜線材は $\mathrm{AOA}^{\prime}$ 線上の部材とする.

地震荷重は水平（ $X$ 方向を正）および鉛直（ $Z$ 方向を正）の加速 度 $A_{H}(x, y), A_{V}(x, y)$ と節点質量 $m_{i}$ を用いて次式で与える. なお, 地震 応答解析では，構造物の減衰定数 $h$ を $2 \%$ とする.

$F_{H}(x, y)=\lambda_{E} \cdot m_{i} \cdot A_{H}(x, y), \quad F_{V}(x, y)=\lambda_{E} \cdot m_{i} \cdot A_{V}(x, y) \quad(17),(18)$
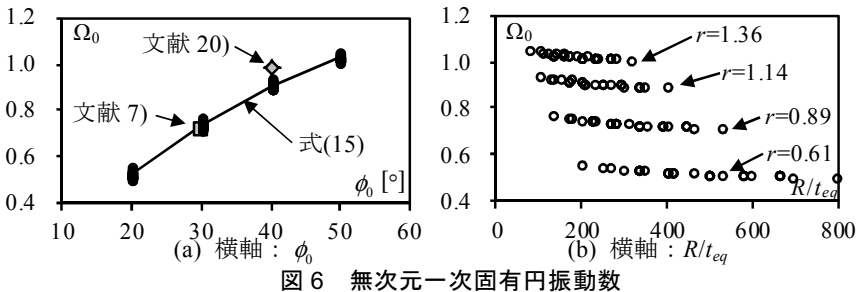

図 6 無次元一次固有円振動数

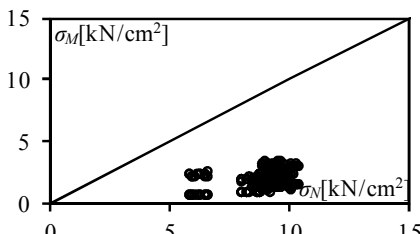

(a) 固定+地震荷重 $\left(\lambda_{E}=1.0\right)^{15}$

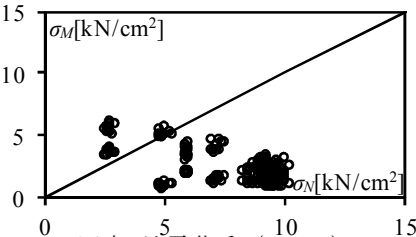

(a) 固定 + 地震荷重 $\left(\lambda_{E}=10\right)$
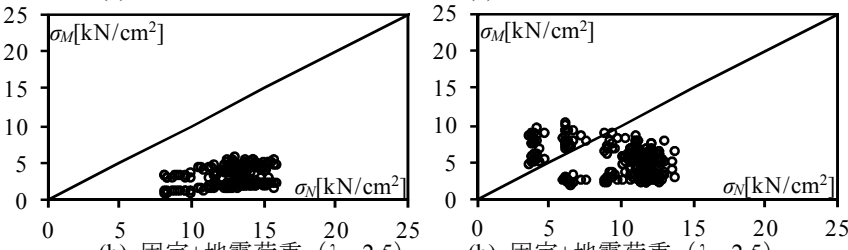

(b) 固定十地震何重 $\left(\lambda_{E}=2.5\right)$

(b) 固定+地震荷重 $\left(\lambda_{E}=2.5\right)$

図 7 フープ材の曲げと軸応力

図 8 稜線材の曲げと軸応力

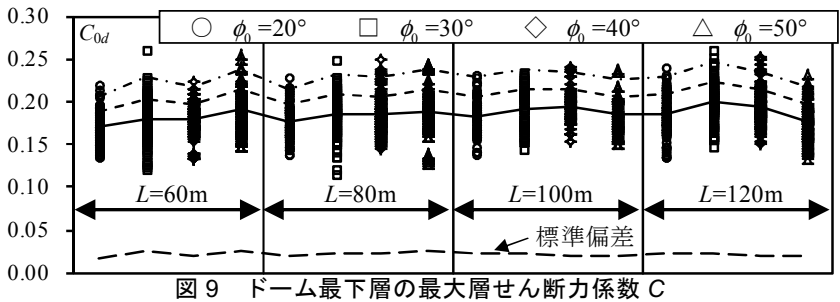

上式の $A_{H}(x, y), A_{V}(x, y)$ は文献 13)を参考に次式で与える.

$$
\begin{aligned}
& A_{H}(x, y)=p_{H} \cdot A_{\max } \cdot\left\{1+\left(\frac{S_{a d 0}\left(T_{1}, h\right)}{A_{\max }}-1\right) \cos \frac{\pi \sqrt{x^{2}+y^{2}}}{L}\right\} \\
& A_{V}(x, y)=p_{V 1} \cdot p_{V 2} \cdot S_{a d 0}\left(T_{1}, h\right) \cdot \frac{x}{\sqrt{x^{2}+y^{2}}} \cdot f
\end{aligned}
$$

ここで， $x, y$ はドーム頂部を原点とする座標， $L$ はスパンを表す.

$A_{\max }$ は $\lambda_{E}=1.0$ に対する入力加速度の最大值を表す．また， $f$ は鉛直 加速度分布の形状を表す，単層ドームは多くのモードが発生するた め, 固有振動モードから地震荷重を算定することは実際的でないと 考え, 本研究では文献 14，21)で地震応答解析の最大の絶対值分布 が台形になることに注目して最大の絶対值分布を包絡する形で鉛直 加速度分布の形状を台形分布とする。つまり，ドーム頂部とテンシ ヨンリング位置では $f=0$ ，それ以外は $f=1$ とする，一例ではあるが， 提案した加速度分布の分析を 5.3 節（図 13）に示す. $S_{a d 0}\left(T_{1}, h\right)$ は 1 次固有周期に対応し, 式(9)より得られる絶対加速度応答スペクトル を表す。なお， $S_{a d 0}$ の值として，その他のモードに対応した值を用 いることも考えられるが，対象ドームの地震時に励起されるモード のほとんどは加速度スペクトル一定領域に位置するため, 1 次モー ド以外の $S_{a d 0}$ もほぼ同じ值になる. $S_{a d 0}\left(T_{1}, h\right)$ を算出する際の $F_{h}(h)$ は 次式を用いる.

$$
F_{h}(h)=\sqrt{\left(1+\alpha h_{s t d}\right) /\left(1+\alpha h_{e q}\right)} \quad ; \quad h_{s t d}=0.05, h_{e q}=0.02
$$

ここで, $\alpha$ は地震動の性質によって定まる值であり, 実地震動 31 波 と BCJ-L2 地震動に対して, それぞれ $\alpha=25,75$ が推奨されている ${ }^{22)}$. 本研究で採用した 12 波の模擬地震動の平均的な低減率は, $\alpha=75$ と した結果と概ね対応することが文献 23)で確認されている.そこで, 
本研究では $\alpha=75$ として $F_{h}(h)$ を計算し, $S_{a d 0}\left(T_{1}, h\right)$ を算出する. 対象 構造物の固有周期は $0.4 \sim 0.7 \mathrm{sec}$ となるため, $S_{a d 0}\left(T_{1}, h\right)$ は $331 \mathrm{~cm} / \mathrm{sec}^{2}$ 程度となる. $p_{H}, p_{v 1}, p_{V 2}$ は補正係数を表し, 次節で説明する.

本節では詳細な検討は省略するが，地震応答解析でのフープ材と 稜線材の軸力が最大となる時刻はそれぞれ異なる.したがって, 対 象とする部材に応じて地震荷重を変更する必要がある. そこで, 本 研究では水平地震荷重 $F_{H}$ と鉛直地震荷重 $F_{V}$ の組合せとして, $F_{H}+F_{V}$ と $F_{H}-F_{V}$ の二種類を設定し, $F_{H}+F_{V}$ はフープ材の軸力, $F_{H}-F_{V}$ は稜線 材の軸力を推定する際に使用する. その理由については後述する.

\section{2 補正係数}

本節では式(19), (20)に示す係数 $p_{H}, p_{V 1}$ および $p_{V 2}$ の值について 検討し, その推定式を提案する. ドーム最下層の層せん断力は水平 振動, 部材軸力は鉛直振動に大きく依存寸ると考えられる. そこで, $p_{H}$ は層せん断力, $p_{V 1}$ と $p_{V 2}$ は部材軸力を推定できるように設定する. (a) 加速度の補正係数

式(20)と地震応答解析の層せん断力の比率を次式で表す.

$$
p_{H}=C_{0 d} /\left\{\sum_{i=1}^{N}\left(A_{H i} \cdot m_{i}\right) / \sum_{i=1}^{N}\left(m_{i} \cdot g\right)\right\}
$$

ここで, $C_{0 d}$ は $\lambda_{E}=1.0$ とした地震応答解析より得られるドーム最下 層の最大層せん断力係数を表す. なお, 前述したように, 本検討で は 12 波の入力地震動による応答のばらつきは考慮せず， $C_{0 d}$ は 12 波の平均值とする. $N$ はテンションリング位置の節点を除く構造物 の節点数を表す. $A_{H i}$ は $p_{H}=1$ とした式(19)より得られる $i$ 節点の水平 加速度である. また, 式(9)の絶対加速度 $S_{a d 0}$ と地震応答解析の最大 鉛直加速度の比率を次式で表す.

$$
p_{V 1}=A_{\text {Vam }} / S_{a d 0}\left(T_{1}, h\right), \quad A_{\text {Vam }}=\sum_{j=1}^{n-1}\left(A_{j} \cdot S_{j}\right) / \sum_{j=1}^{n-1} s_{j}
$$

ここで, $A_{\text {Vam }}$ は $\mathrm{AOA}^{\prime}$ 上の節点で生じた最大鉛直加速度を $j$ 周の面積 (図 1 参照) で重み付き平均した值である. なお， $A_{j}$ は $\mathrm{AOA}^{\prime}$ 線上 で発生する $\lambda_{E}=1.0$ とした時刻歴地震応答解析の $j$ 周の最大鉛直応答 加速度, $s_{j}$ は $j$ 周の面積を表す.

$p_{H}$ と半開角 $\phi_{0}$ の関係を図 $10, p_{V 1}$ と半開角 $\phi_{0}$ の関係を図 11 に示 す. 図中のプロットはスパン $L$, 部材細長比 $\lambda_{0}$ および分割数 $n$ の違 いも含めた表 3 の断面性能を有する各モデルの結果, 実線はその平 均值を表す. 図 10 より, $p_{H}$ は半開角 $\phi_{0}$ や部材細長比 $\lambda_{0}$ などにやや 依存するが, その影響は小さく,ほぼ一定值とみなすことができる. また, 図 11 より, $p_{V 1}$ は部材細長比 $\lambda_{0}$ の影響は小さく, 半開角 $\phi_{0}$ に 依存する. 以上を勘案し, 本研究では式(19), (20)に用いる $p_{H}$ およ び $p_{V 1}$ として次の補正係数を提案する.

$$
p_{H(a)}=0.9, \quad p_{V 1(a)}=0.609 \sqrt{\phi_{0}} /\left(1-1.488 \phi_{0}+1.155 \phi_{0}^{2}\right) \quad \text { (25), (26) }
$$

なお，上式はモデルごとのばらつきを考慮し，安全側に評価するた めに, 平均値+標準偏差に対応寸るように作成している (式中の $\phi_{0}$ の 単位は $\mathrm{rad})$. 式(25), (26)の值を図 10，11 中に破線で示す。図 10, 11 より, 提案式は解析結果に対応していることが確認できる.

\section{(b) 軸力推定のための補正係数}

式(19), (20)と式(25), (26)から最大応答加速度を近似的に推定で きるが，ドーム部材の最大軸力の推定には，妥当な $p_{V 2}$ の值を検討 する必要がある，そこで，提案式（式(19)，(20)と式(25)，(26)）か ら得られる軸力と地震応答解析の最大軸力を比較する. なお, 前述 したように, フープ材は図 1 に示す AOA'線に近接する部材, 稜線
材は $\mathrm{AOA}^{\prime}$ 線上の部材とする. 時刻歴応答および提案した地震荷重 によるそれぞれの軸力の違いは，次式に示す $p_{V 2}$ で検討できる.

$$
p_{V 2}=\left({ }_{d} N-{ }_{s} N_{H}\right) /{ }_{s} N_{V}
$$

ここで, ${ }_{d} N$ は $\lambda_{E}=1.0$ とした時刻歴地震応答解析のドーム部材の最大 軸力の絶対值， ${ }_{s} N_{H}$ は式(17), (25)の水平地震荷重のみを作用させた 時の静的解析の最大軸力の絶対值, ${ }_{s} N_{V}$ は式(18), (26)で $p_{V 2}=1$ とし て算定した鉛直地震荷重のみを作用させた時の静的解析による最大 軸力の絶対值を表す。この時, 注目する部材は地震応答解析時に最 大值となる部材とする．また，前述したように，本検討では 12 波の 入力地震動による応答のばらつきは分析せず， ${ }_{d} N$ は 12 波の平均值 とする. 本研究ではフープ材と稜線材に対応して, それぞれ $F_{H}+F_{V}$ と $F_{H}-F_{V}$ の 2 種類を設定するため, フープ材には $F_{H}+F_{V}$ の地震荷重 に対する $p_{V 2}$ ，稜線材には $F_{H}-F_{V}$ に対する $p_{V 2}$ を計算する.

$p_{V 2}$ とドームの半開角 $\phi_{0}$ の関係を図 12 に示す. 図中のプロットは スパン $L$, 部材細長比 $\lambda_{0} お$ よび分割数 $n$ の違いも含めた全モデルの 結果, 実線はその平均值を表す. 図 12 より, $p_{V 2}$ はドームの半開角 $\phi_{0}$ に依存する，そこで，本研究ではこの性状を反映し， $p_{V 2}$ の近似值と して次式を提案し，これを補正係数として式（20）に用いる.

$$
\begin{array}{ll}
F_{H}+F_{V}: & p_{V 2(a)}=1.000 \sqrt{\phi_{0}} /\left(1+0.750 \phi_{0}-1.090 \phi_{0}{ }^{2}\right) \\
F_{H^{-}} F_{V}: & p_{V 2(a)}=1.522 \sqrt{\phi_{0}} /\left(1-0.986 \phi_{0}+0.948 \phi_{0}{ }^{2}\right)
\end{array}
$$

なお，上式は全モデルの係数のばらつきを考慮し，安全側に評価す るために, 平均值+標準偏差に対応するように作成している（ $\phi_{0}$ の 単位は $\mathrm{rad}$ )。式(28), (29)の值を図 12 中に破線で示す。図 12 より, 近似式は解析結果に概ね対応する。

\section{3 加速度分布}

一例として, スパン $L=100 \mathrm{~m}$, 半開角 $\phi_{0}=30^{\circ}$, 部材細長比 $\lambda_{0}=50$ のドームに注目する，また，地震荷重は $F_{H}+F_{V}$ とする，提案した補 正係数（式(25)，(26)，(28)）を用いた式(19)，(20)による加速度分布 を図 13 に示寸，図 13(a)より，水平加速度はドーム頂部が最も大き
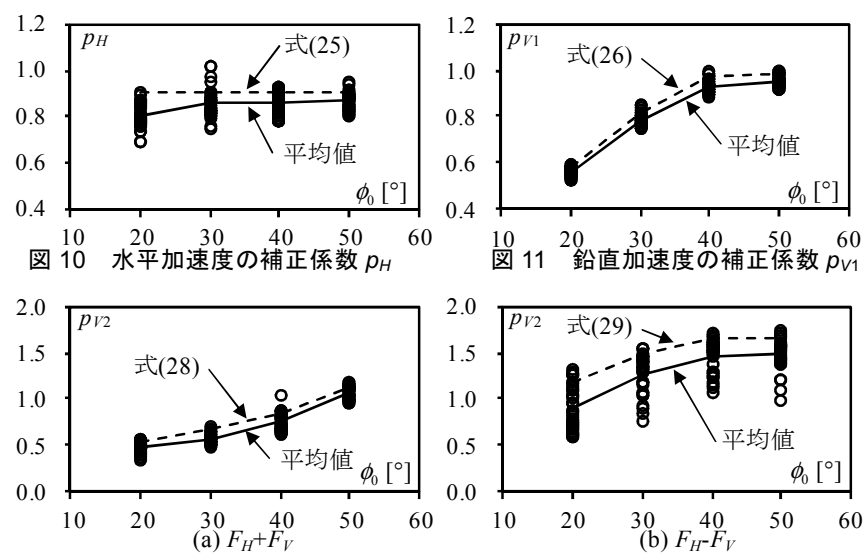

図 12 鉛直加速度の補正係数 $p_{V 2}$

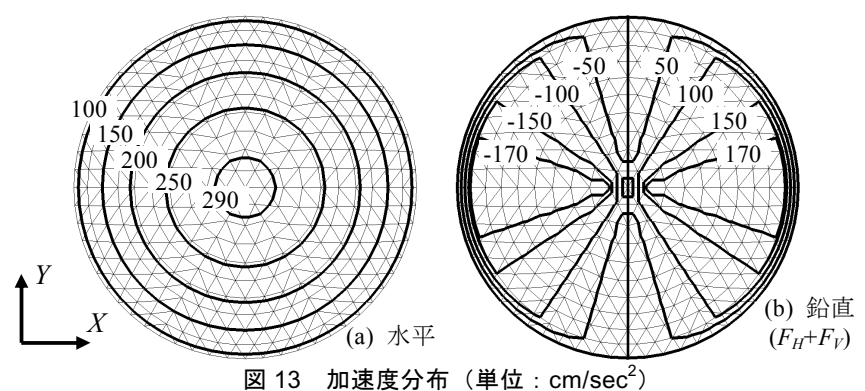


$く, 300 \mathrm{~cm} / \mathrm{sec}^{2}$ 程度となる. 図 13(b)より, 鉛直加速度は $\mathrm{AO}$ 線上に おいて台形分布となり, その最大值は $180 \mathrm{~cm} / \mathrm{sec}^{2}$ 程度となる. また, 周方向はドーム頂部とテンションリング位置を除いて $\mathrm{AOA}^{\prime}$ 線上が 最も大きく, その箇所から離れるにつれて小さくなる.

\section{6. 地震荷重の精度}

提案した地震荷重の精度および有効性を検討する.このため, 地 震応答解析と提案した補正係数を用いて算定される地震荷重に対す る静的解析の結果をそれぞれ比較する.

\section{1 ドーム最下層の最大層せん断力}

$\lambda_{E}=1.0$ とした地震応答解析と静的解析の最大層せん断力の比率を 半開角 $\phi_{0}$ ごとに図 14 に示寸. 図中のプロット $(\bigcirc, \square, \diamond, \triangle)$ はスパン $L$, 部材細長比 $\lambda_{0}$ および分割数 $n$ の違いも含めた全モデル の結果を表す. また, 実線はその平均值, 破線は平均值墂準偏差, 一点鎖線は平均值 $\pm 2 \times$ 標準偏差を表す. なお， 12 波の入力地震動に よる応答のばらつきも分析する. 図 14 より, 提案した地震荷重によ る層せん断力と応答解析結果の比率はスパン $L$ に僅かに依存するが, $L=60 \mathrm{~m}$ では 0.90 程度, $L=120 \mathrm{~m}$ では 0.97 程度であり, スパン $L$ の影 響は小さい. また, 変動係数は最も大きい $L=60 \mathrm{~m}, \phi_{0}=30^{\circ}$ のドーム で $13 \%$ 程度, 最も小さい $L=60 \mathrm{~m}, \phi_{0}=20 \circ$ のドームで $10 \%$ 程度となる. 平均值+標準偏差を見れば比率は 1.1 程度となり, ほぼ安全側に評価 できる. 12 波のばらつきの考慮のため, 提案した式(17), (18)から 計算する地震荷重にある一定の係数を乗ずれば, 設計等に使用可能 な地震荷重が算定できる可能性がある. たとえば, 平均值+標準偏 差の結果を用いるならば, 1.1 , 平均値 $+2 \times$ 標準偏差の結果を用いる ならば, 提案した地震荷重による静的解析の結果に 1.2 倍程度乗ず れば, さらに安全側の評価となる. なお, 後述の耐震性能評価指標 では, 式(17)の地震荷重で計算された平均值で評価した層せん断力 係数を基本としている. 耐震性能を安全側に評価する際は, 平均値標準偏差や平均值-2×標準偏差の結果を用いて, 後述の耐震性能指標 に 0.8 あるいは 0.7 を乗ずれば安全側となる.

\section{2 部材軸力}

$\lambda_{E}=1.0$ とした時刻歴地震応答解析と静的解析の軸力を比較する. 本節では図 1 に示される $\mathrm{AOA}^{\prime}$ 線上の稜線材とその部材に近接する フープ材に注目する.

例として $, L=100 \mathrm{~m}, \phi_{0}=30^{\circ}, \lambda_{0}=50$ のドームのフープ材と稜線材 の軸力分布を図 15,16 に示寸. 図中の応答解析の結果は 12 波の入 力地震動による応答の平均值を示寸. また, 静的解析では $F_{H}+F_{V}$ と $F_{H}-F_{V}$ の 2 種類の地震荷重について検討する. 図 15 より, フープ材 に注目すると $F_{H}+F_{V}$ では 7 周目, $F_{H}-F_{V}$ では 2 周目の部材の軸力が 最も大きくなる. また, $F_{H}+F_{V}$ の荷重は応答解析の軸力分布を包絡 する. 図 16 より, 稜線材に注目すると $F_{H}+F_{V}$ では 5,6 周目の間, $F_{H}-F_{V}$ では 9, 10 周目の間の部材の軸力が最も大きくなる. また, $F_{H}-F_{V}$ の荷重は応答解析の軸力分布を包絡する. 以上の結果から, フープ材の最大軸力の模擬には $F_{H}+F_{V}$, 稜線材の最大軸力の模擬に は $F_{H}-F_{V}$ の地震荷重を用いると精度がよい. なお, 設計に利用する 際は, $F_{H}+F_{V}$ と $F_{H}-F_{V}$ の結果を比較し, それぞれの結果から大きい 方を採用すれば妥当な值となる. ただし, 後述の PO 解析では, 解 析途中で荷重を変更することができないので，フープ材の検討では $F_{H}+F_{V}$, 稜線材の検討では $F_{H}-F_{V}$ の地震荷重を用いる.

フープ材と稜線材の軸力について応答解析と静的解析の比較を図
17，18 に示寸. 図中の結果はドームのスパン $L$ が $100 \mathrm{~m}$ のモデルの 例である. 前節と同様に, 1 個のモデルの静的解析結果に対して 12 波のそれぞれの值が図に示されている.また，注目寸る部材は $\mathrm{AOA}^{\prime}$ 線上に近接する部材とする。 なお, 荷重として, (1)地震荷重のみ $\left(\lambda_{E}=1.0\right)$, (2)固定荷重+地震荷重 $\left(\lambda_{E}=1.0\right)$, (3)固定荷重+地震荷重 $\left(\lambda_{E}=2.5\right)$ の 3 種類を設定する. また, 静的解析の地震荷重として, フープ材の軸力を評価する際は $F_{H}+F_{V}$, 稜線材の軸力を評価する際 は $F_{H}-F_{V}$ を使用している. 図17(a)，18(a)を見れば，応答解析と静的 解析の結果は概ね対応する.ただし, 同じ地震動強さ $\lambda_{E}$ に対して 12 波の応答值には多少のばらつきがあるので, 応答解析と静的解析に は 1 対 1 の対応はなく, ある幅のばらつきの中での対応関係が確認 できる. なお, 図 17(b)(c), 18(b)(c)から理解できるように, 固定荷 重の影響を含めて対応関係を分析すると，ばらつきの幅は相対的に 小さくなる. また, 地震荷重を $\lambda_{E}=2.5$ まで増加させても応答解析と 静的解析の結果は比較的に精度よく対応している．したがって, 提 案した地震荷重を用いれば $\lambda_{E}=2.5$ 相当の地震入力に対しても部材の 軸力算定に適用できると考えられる注1).

\section{7. 地震荷重の適用範囲および耐荷性能}

ドームの幾何学的非線形性および材料学的非線形性を考慮した地 震応答解析と PO 解析の結果を比較し, 提案した地震荷重の精度, 有効性，適用範囲，また，ドームの耐荷性能を分析する．本研究で は塑性ヒンジが初めて発生した地震動強さ（以降, 初期降伏地震動 強さ）を $\lambda_{E y}$ とする。 ここでは，例として，スパン $L=100 \mathrm{~m}$, 半開角 $\phi_{0}=20,50^{\circ}$, 部材細長比 $\lambda_{0}=40,80$ のモデルの結果を示す.

PO 解析ではまず固定荷重を作用させ，その後，提案した補正係 数を代入して式(17)，(18)で計算される地震荷重を作用させる. 表 3 の断面性能を有するドームはフープ材で初めて塑性ヒンジが発生す る.また，降伏するフープ材は図 15 に示すように 7 周目付近の部材 であり, 終局状態ではその部材近傍の節点が大きく変形するため, 本検討では地震荷重として $F_{H}+F_{V}$ を採用する.

地震応答解析では, 数值積分法に Newmark $-\beta$ 法 $(\beta=1 / 4)$ を採用 し，20 秒間の応答解析を行う. 解析ではまず固定荷重を作用させ, その後， $X$ 方向に地震動を作用させる.

地震応答解析より得られる最大鉛直変位は入力地震動によってそ の発生箇所が異なる。したがって, 本章では PO 解析において最大 鉛直変位がスパン $L$ の $1 / 300$ に達した時の節点を注目節点とし，応 答解析と PO 解析の結果を比較する. PO 解析と応答解析の荷重変位 関係を図 19 に示寸，図中の○は 12 波の応答解析の結果，実線は同 じ $\lambda_{E}$ に対する平均值, 破線は PO 解析の結果, $\square$ は初期降伏地震動 強さ $\lambda_{E y}$ を表す. $\mathrm{PO}$ 解析の地震動強さ $\lambda_{E i}$ は次式で与えられる.

$$
\lambda_{E i}=\left(P_{i}-P_{d}\right) / P_{e 0}
$$

ここで, $P_{i}$ は $i$ ステップの固定荷重を含み地震荷重も考慮した鉛直 成分の荷重, $P_{d}$ は固定荷重, $P_{e 0}$ は $\lambda_{E}=1.0$ とした式(18)より得られる 固定荷重は除く地震荷重の鉛直成分を表す. 図 19 より, 初期降伏ま では PO 解析と応答解析の結果は概初対応寸ることが確認できる. PO 解析では最大耐力に達した後, 部材細長比 $\lambda_{0}$ が大きいと, 最大 耐力に達した後の荷重の低下が大きい. 図 19 より, 降伏後は応答解 析と PO 解析の結果は異なり, 特に, 応答解析結果は耐力が増加し 続けるが, PO 解析の結果は最大耐力に達した後, 荷重が低下寸る. また，提案した地震荷重は弾性範囲でのドーム部材の軸力を評価す 
るものであるため，塑性後のドーム部材に生じる曲げの増幅等を考 慮することはできない, したがって, 提案した地震荷重と PO 解析 から塑性後の応答性状を推定することは困難である. そこで, 本研 究では次章で述べる動的勒性指標 ${ }_{d} F て ゙$ 塑性後の耐力評価を行う.

\section{8. 弾塑性地震応答解析に基づいた耐震性能評価}

本章では単層ラチスドームの耐震性能を確認するとともに，その 評価方法を示す. 本研究ではまず, 12 波の入力地震動による応答の 平均值に注目して議論し，12 波のばらつきを含めた評価は 8.3 節で 述べる. 半開角 $\phi_{0}$ が大きく, パラメータ $\xi_{0}$ が小さいモデルについて は, 個材座屈が発生する場合も想定されるが, 本研究では全体座屈 に焦点を当るためにその性状は深く分析せず，個材座屈が先行する ドームの耐震性能評価については今後の研究課題とする.

地震荷重が作用した時, 単層ラチスドームは文献 7)に示されるよ うに, フープ材の塑性後は稜線材上の節点が鉛直下方に大きく変形 する. ただし, 半開角 $\phi_{0}=20^{\circ}$ モデルは, 稜線材以外の複数の箇所 でも大きく変形し, 他のドームと崩壊性状が大きく異なるため, 後 述で説明する動的勒性指標 ${ }_{d} F$ が高く評価される. また, 初期降伏地 震動強さ $\lambda_{E y}$ も 5.0 を超え, 耐震性も高いので, 本検討では半開角 $\phi_{0}=20^{\circ}$ モデルは除外する.

\section{1 動的勒性指標}

耐震性能指標として動的勒性指標 ${ }_{d} F$ を採用する. ドームの動的靵 性指標 ${ }_{d} F$ は文献 7，24)を参考に次式で与える.

$$
{ }_{d} F=\lambda_{E}{ }^{c r} / s \lambda_{E y}
$$

ここで, $\lambda_{E}{ }^{c r}$ は限界地震動強さ, $\lambda_{E y}$ は提案した地震荷重を用いた PO
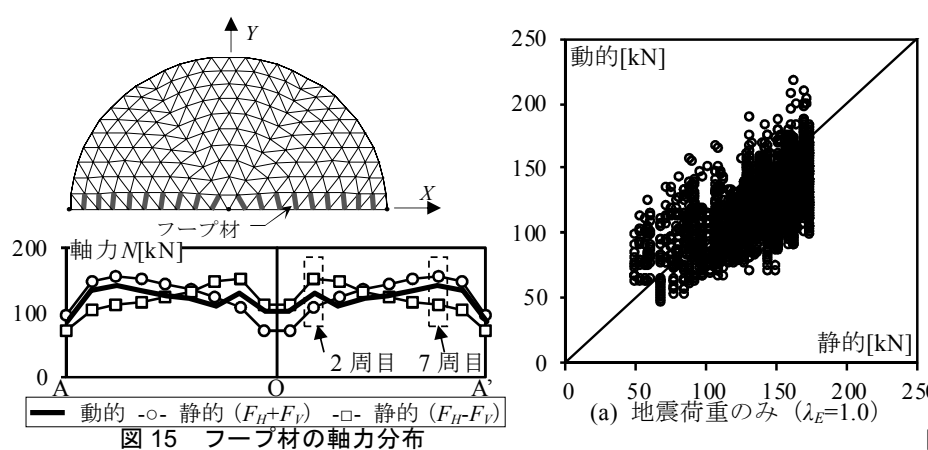

$\Delta Y$
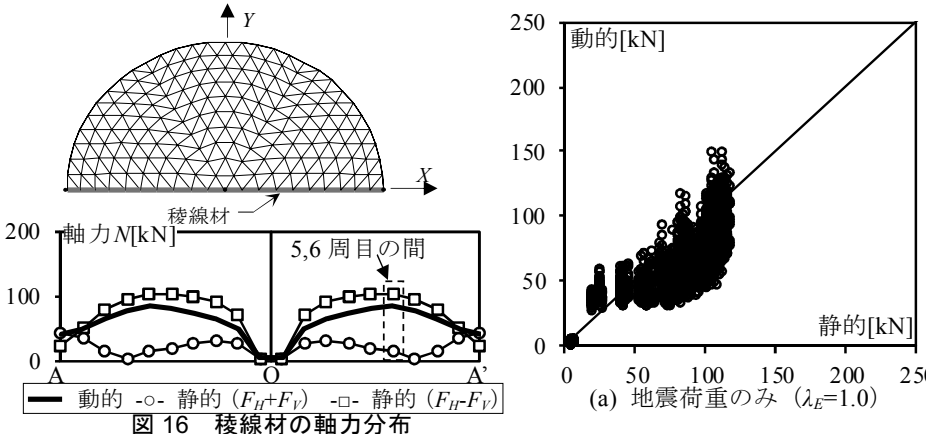

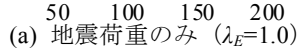

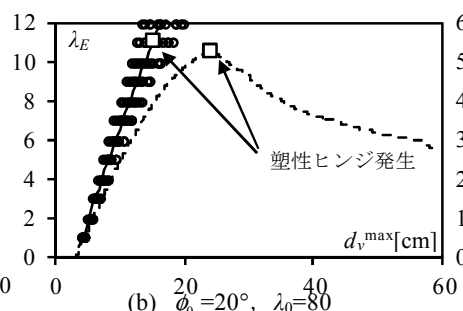

(a) ${ }_{0}^{20}=20^{\circ}, \quad \lambda_{0}=40$

図 19 荷重変位関係 $(L=100 \mathrm{~m}$ ，実線：
解析から計算される初期降伏地震動強さを表す。なお, 文献 7)では ${ }_{d} F$ 值を算出する際, 分母を弾塑性地震応答解析から直接に得られる 降伏地震動強さを用いている。しかし, 前章において確認したよう に, 応答解析と PO 解析の降伏地震動強さは概ね等しく, また, 本 研究では耐震性能を PO 解析に基づいて算定することを目的として いるため, PO 解析から降伏地震動強さを算出する. 対象構造物は フープ材で初めて塑性ヒンジが発生するため, 7 章と同様に, 静的 解析で用いる地震荷重は $F_{H}+F_{V}$ とする.

本研究では限界変形のパラメータをドームの最大鉛直変位の塑性 率 $\mu$ とし, 次式で与える.

$$
\mu={ }_{d} d_{v}{ }^{\max } /{ }_{s} d_{v y}
$$

ここで, ${ }_{d} d_{v}{ }^{\max }$ は応答解析から計算する最大鉛直変位, ${ }_{s} d_{v y}$ は提案し た地震荷重 $\left(F_{H}+F_{V}\right)$ を用いた $\mathrm{PO}$ 解析による初期降伏鉛直変位を表 す. なお, $\mu=2 \sim 3$ 程度は鉛直変位がスパン $L$ の $1 / 300$ に対応する. 応答解析では入力地震動およびドームの形状等によって最大鉛直変 位が発生する節点が異なり，ここでは最大変形が発生する節点を対 象とし, モデルおよび地震動や地震レベルごとに注目節点が変わる.

各モデルの限界地震動強さ $\lambda_{E}{ }^{c r}$ と塑性率 $\mu$ の関係を表 4 に示す.
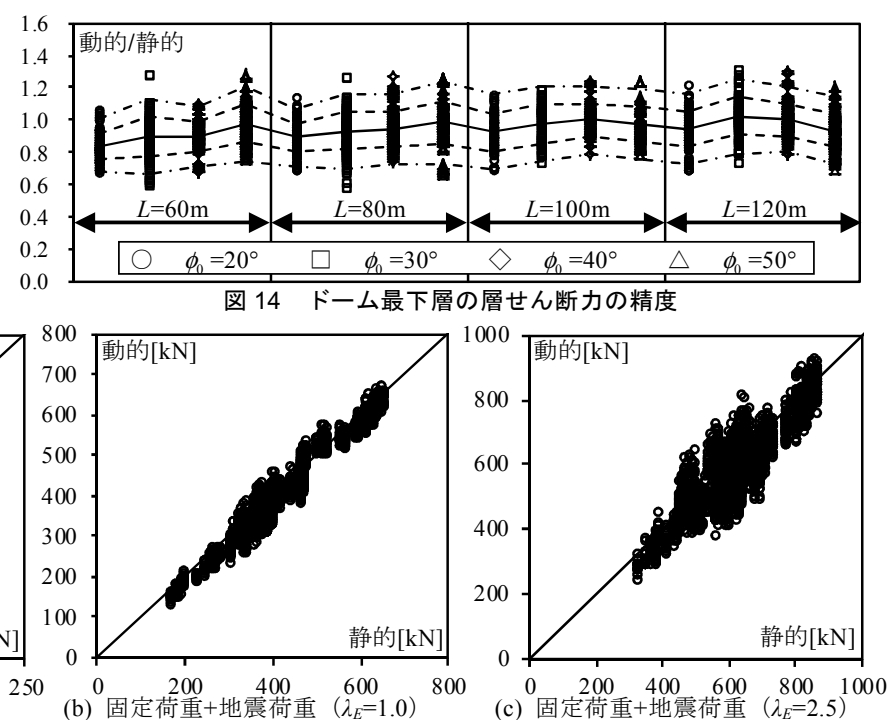

図 17 フープ材の軸力の精度 $(L=100 \mathrm{~m})$

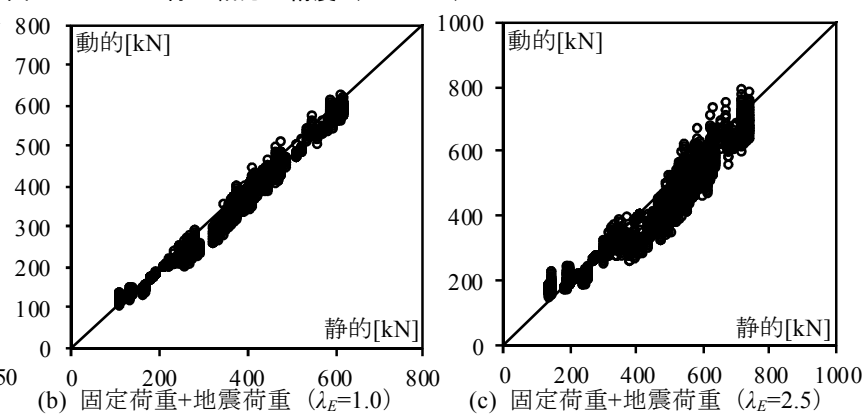

図 18 稜線材の軸力の精度 $(L=100 \mathrm{~m})$

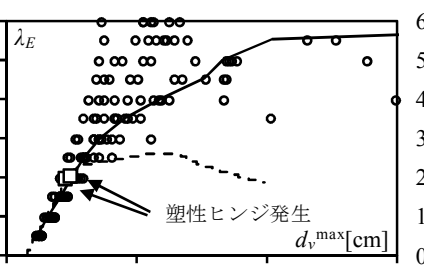

(c) $\phi_{0}^{20}=50^{\circ}, \quad \lambda_{0}=40$

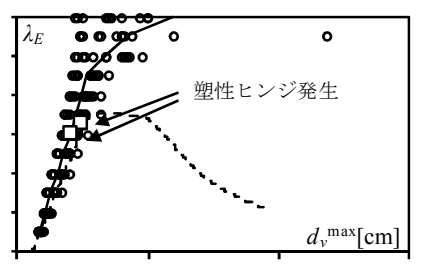

(d) $\stackrel{20}{\phi_{0}}=50^{\circ}, \quad \lambda_{0}=80$

応答解析 (平均), 破線 : PO 解析) 
表中の $\lambda_{E}^{c r}$ と $\mu$ は 12 波の平均值を表す. また, 括弧内の数值は 4.1 節で検討した固定荷重に対する対象構造物の耐力（弾塑性座屈荷重 の倍率)を表し, $\mu=1$ の結果は $\lambda_{s} \lambda_{E y}$ に概ね対応する. 表中の下線は $\xi_{0}=4$ 以下のモデルの結果を表す. 本研究では中間節点を設けておらず, 個材座屈を考慮していない. そのため, 塑性後の耐力評価で $\xi_{0}=4$ 以 下のモデルの結果を使用する際はこの点に留意する必要がある. 表 4 より, 同じ $\mu$ に対して半開角 $\phi_{0}$ が大きいと $\lambda_{E}{ }^{c r}$ は小さくなる. 表 4 では省略しているが, 前章で対象とした $\phi_{0}=20^{\circ}$ のモデルの降伏地震 動強さ $\lambda_{E y}$ は 5.0 を超えるため, 高い耐震性能を持つ. $\phi_{0}=30^{\circ}, 40^{\circ}$ のモデルは $\lambda_{E}=2.5$ の地震入力に対して弾性となるが, それ以上の地 震入力ではドームは塑性化する. なお, スパン $L=100 \mathrm{~m}$, 半開角 $\phi_{0}=30^{\circ}$, 部材細長比 $\lambda_{0}=50$ のモデルでは, 限界変形として $\mu=2$ 程度 に対して $\lambda_{E}^{c r}$ は 7.6 となり, 安全限界レベルの地震動強さを超える.

表 4 で示す範囲ではほとんどの場合, 塑性率が 2 に対して, $\phi_{0}=50^{\circ}$ の 18 例を除くと, 対応する地震動強さの平均は安全限界の 5.0 を超 す. また, 塑性率が 3 に対して $\phi_{0}=50^{\circ}$ の 10 例以外, 塑性率が 4 に
対して $\phi_{0}=50^{\circ}$ の 5 例以外のモデルの地震動強さ $\lambda_{E}$ は安全限界の 5.0 を超える.したがって, 固定荷重に対して 2 倍程度（平均で 2.6 程 度）で設計したドームでは， $\phi_{0}=30^{\circ}, 40^{\circ}$ の半開角では相当に耐震 性能が高いと判断できる.

式(31)より得られる動的勒性指標 ${ }_{d} F$ と塑性率 $\mu$ の関係を図 20 に 示す. 例として, 部材細長比 $\lambda_{0}=60$, 分割数 $n=10$ のモデルを対象と する. 図中のプロットはスパン $L$, 半開角 $\phi_{0}$ の違いを含めた各モデ ルの結果を示し, 実線はその平均値, 破線は平均值-標準偏差を表す. なお, 前述したように, 本検討では 12 波の入力地震動による応答の ばらつきは含めず，12 波に対する平均值を分析する。図 20 より, 動的勒性指標 ${ }_{d} F$ は塑性率 $\mu$ に伴い増加し, 各プロットの同じ $\mu$ に対 する変動係数は 3 5\%程度となる. また，図は省略するが， $\mu=2 \sim 3$ に対して ${ }_{d} F$ 值（ $\mu$ に対する各モデルの平均值）は $\lambda_{0}=40$ で $1.9 \sim 2.1$ 程度, $\lambda_{0}=50$ で $1.8 \sim 2.0$ 程度, $\lambda_{0}=60$ で $1.7 \sim 1.9$ 程度, $\lambda_{0}=70$ で $1.6 \sim$ 1.8 程度, $\lambda_{0}=80$ で $1.5 \sim 1.7$ 程度となる. 部材細長比 $\lambda_{0}$ が大きくなる とやや ${ }_{d} F$ 值は低くなる.したがって, ${ }_{d} F$ 值はスパン $L$ や半開角 $\phi_{0}$ に

表 4 限界地震動強さ $\lambda_{E}{ }^{c r}$ (12 波の平均値)

\begin{tabular}{|c|c|c|c|c|c|c|c|c|c|c|c|c|c|c|c|c|c|}
\hline \multirow[b]{2}{*}{$L[\mathrm{~m}]$} & \multirow[b]{2}{*}{$n$} & \multirow[b]{2}{*}{$\mu$} & \multicolumn{5}{|c|}{$\phi_{0}=30\left[^{\circ}\right]$} & \multicolumn{5}{|c|}{$\phi_{0}=40\left[^{\circ}\right]$} & \multicolumn{5}{|c|}{$\phi_{0}=50\left[^{\circ}\right]$} \\
\hline & & & $\lambda_{0}=40$ & $\lambda_{0}=50$ & $\lambda_{0}=60$ & $\lambda_{0}=70$ & $\lambda_{0}=80$ & $\lambda_{0}=40$ & $\lambda_{0}=50$ & $\lambda_{0}=60$ & $\lambda_{0}=70$ & $\lambda_{0}=80$ & $\lambda_{0}=40$ & $\lambda_{0}=50$ & $\lambda_{0}=60$ & $\lambda_{0}=70$ & $\lambda_{0}=80$ \\
\hline \multirow{8}{*}{60} & \multirow{4}{*}{10} & 1 & $4.2(2.8)$ & $4.1(2.3)$ & 5.2(2.3) & $6.2(2.5)$ & $6.5(2.4)$ & $3.4(3.2)$ & $3.9(2.7)$ & $4.1(2.9)$ & $3.9(2.4)$ & $4.6(3.2)$ & $2.7(2.7)$ & $3.2(3.0)$ & $3.6(3.1)$ & $3.8(3.2)$ & $3.9(3.1)$ \\
\hline & & 2 & 8.0 & 6.8 & 8.2 & 9.3 & 9.0 & 6.9 & 7.0 & 6.4 & 5.8 & 6.5 & 4.7 & 5.1 & 5.5 & 5.5 & 5.4 \\
\hline & & 3 & 9.0 & 7.8 & 8.8 & 10.2 & 10.2 & 7.9 & 7.5 & 6.9 & 6.4 & 7.1 & 5.2 & 5.9 & 6.2 & 6.0 & 5.8 \\
\hline & & 4 & 9.9 & 8.6 & 9.2 & 10.7 & 10.8 & 8.6 & 7.9 & 7.2 & 6.7 & 7.7 & 5.6 & 6.4 & 6.8 & 6.4 & 6.1 \\
\hline & \multirow{4}{*}{6} & 1 & $4.0(2.4)$ & $3.8(2.5)$ & $4.7(2.9)$ & $4.5(2.9)$ & $5.1(3.0)$ & $2.7(2.6)$ & $3.0(2.8)$ & $3.4(2.8)$ & $3.5(2.8)$ & 3.9(2.7) & $3.1(3.2)$ & $2.3(2.5)$ & $2.8(2.7)$ & 3.2(2.8) & $3.5(2.8)$ \\
\hline & & 2 & 8.0 & 7.0 & 7.2 & 6.5 & 7.5 & 5.6 & 5.2 & 5.1 & 5.3 & $\underline{5.6}$ & 6.3 & 3.7 & $\underline{4.0}$ & $\underline{4.3}$ & $\underline{4.7}$ \\
\hline & & 3 & 9.0 & 7.9 & 8.3 & 7.2 & 8.1 & 6.5 & 5.8 & 5.6 & 5.9 & $\underline{6.1}$ & 7.8 & 4.1 & $\underline{4.4}$ & 5.0 & 5.8 \\
\hline & & 4 & 9.5 & 8.2 & 8.9 & 7.8 & 8.4 & 7.0 & 6.2 & 5.9 & 6.3 & 6.6 & 8.2 & 4.3 & $\underline{4.6}$ & 5.3 & 6.2 \\
\hline \multirow{8}{*}{80} & \multirow{4}{*}{10} & 1 & $3.7(2.5)$ & $4.3(2.3)$ & $\mathbf{5 . 5}(2.3)$ & 6.1(2.4) & $6.5(2.4)$ & $3.3(3.0)$ & $3.6(2.4)$ & $4.1(2.9)$ & $4.0(2.3)$ & $4.2(2.9)$ & $2.9(2.7)$ & $3.2(2.8)$ & $3.2(2.8)$ & $3.3(2.8)$ & $3.7(3.0)$ \\
\hline & & 2 & 6.9 & 7.1 & 8.4 & 8.7 & 9.0 & 6.5 & 5.8 & 6.4 & 5.6 & 5.7 & 5.0 & 4.9 & 4.5 & 4.5 & 5.0 \\
\hline & & 3 & 8.2 & 8.1 & 9.7 & 9.7 & 10.2 & 7.2 & 6.6 & 7.0 & 6.1 & 6.3 & 5.8 & 5.6 & 4.9 & 4.9 & 5.4 \\
\hline & & 4 & 8.9 & 8.6 & 10.3 & 10.8 & 11.2 & 7.8 & 7.1 & 7.4 & 6.5 & 6.9 & 6.3 & 6.1 & 5.4 & 5.5 & 5.7 \\
\hline & \multirow{4}{*}{8} & 1 & $4.0(2.8)$ & $4.6(2.6)$ & $4.8(2.6)$ & $5.4(3.0)$ & $\mathbf{6 . 0}(2.4)$ & $2.6(2.3)$ & $3.5(2.9)$ & $3.7(2.8)$ & $4.1(3.0)$ & $4.1(2.9)$ & $2.9(3.0)$ & $2.3(2.4)$ & $3.4(2.8)$ & $3.4(2.8)$ & $3.4(2.8)$ \\
\hline & & 2 & 8.1 & 7.7 & 7.6 & 7.9 & 8.1 & 4.9 & 6.1 & 5.4 & 5.9 & 5.3 & 5.2 & 3.4 & 4.5 & 4.2 & $\underline{4.3}$ \\
\hline & & 3 & 9.2 & 8.9 & 9.0 & 8.7 & 9.1 & 5.6 & 6.6 & 6.0 & 6.6 & 5.8 & 6.1 & 3.8 & 5.0 & 4.7 & 4.8 \\
\hline & & 4 & 10.0 & 9.6 & 9.6 & 9.2 & 9.9 & 6.1 & 7.2 & 6.5 & 7.0 & 6.3 & 6.8 & 4.1 & 5.6 & 5.0 & 5.1 \\
\hline \multirow{4}{*}{100} & \multirow{4}{*}{10} & 1 & $4.1(2.5)$ & $4.3(2.3)$ & $5.8(2.4)$ & $6.0(2.4)$ & $6.3(2.3)$ & $3.1(2.9)$ & $3.4(2.2)$ & $3.7(2.6)$ & $4.3(2.4)$ & $4.2(3.0)$ & $2.1(2.1)$ & $2.9(2.7)$ & $2.9(2.7)$ & $3.3(2.6)$ & $3.5(3.0)$ \\
\hline & & 2 & 7.8 & 7.6 & 9.0 & 8.8 & 8.8 & 6.1 & 5.5 & 5.8 & 6.3 & 6.0 & 3.6 & 4.5 & 4.4 & 4.8 & 4.8 \\
\hline & & 3 & 8.9 & 8.4 & 9.9 & 9.5 & 10.0 & 7.1 & 5.9 & 6.2 & 7.0 & 6.6 & 4.2 & 5.2 & 5.1 & 5.3 & 5.4 \\
\hline & & 4 & 9.7 & 9.0 & 10.5 & 10.3 & 11.0 & 7.7 & 6.2 & 6.5 & 7.4 & 7.1 & 4.6 & 5.7 & 5.4 & 5.8 & 5.8 \\
\hline \multirow{8}{*}{120} & \multirow{4}{*}{10} & 1 & $3.5(2.4)$ & $4.1(2.3)$ & $\mathbf{5 . 0}(2.3)$ & $6.2(2.4)$ & $6.4(2.3)$ & $2.9(2.8)$ & $3.3(2.4)$ & $3.5(2.7)$ & $4.3(2.4)$ & $4.6(3.0)$ & $2.1(2.2)$ & $2.7(2.6)$ & $3.2(2.8)$ & $3.6(2.9)$ & $3.8(2.9)$ \\
\hline & & 2 & 6.8 & 7.0 & 8.3 & 9.2 & 9.3 & 5.7 & 6.0 & 5.7 & 6.1 & 6.2 & 3.6 & 4.5 & 4.9 & 5.1 & 5.0 \\
\hline & & 3 & 7.8 & 7.9 & 9.1 & 10.3 & 10.1 & 6.5 & 6.5 & 6.1 & 6.7 & 6.8 & 4.5 & 5.1 & 5.7 & 5.5 & 5.4 \\
\hline & & 4 & 8.4 & 8.6 & 9.7 & 10.9 & 10.8 & 7.1 & 6.9 & 6.6 & 7.1 & 7.3 & 4.8 & 5.7 & 6.0 & 6.0 & 5.8 \\
\hline & \multirow{4}{*}{12} & 1 & $4.0(2.6)$ & $4.9(2.4)$ & $6.0(2.4)$ & $6.8(2.4)$ & $7.5(2.4)$ & $2.9(2.5)$ & $3.2(2.3)$ & $4.1(2.3)$ & $4.6(2.3)$ & $4.8(2.4)$ & $2.9(2.8)$ & $2.7(2.2)$ & $3.2(2.3)$ & $3.5(2.4)$ & $3.7(2.4)$ \\
\hline & & 2 & 7.7 & 9.1 & 9.0 & 9.4 & 10.4 & 5.6 & 5.5 & 6.2 & 6.3 & 6.8 & 5.3 & 4.3 & 4.7 & 5.0 & 5.4 \\
\hline & & 3 & 8.7 & 9.8 & 10.1 & 11.1 & 11.7 & 6.3 & 6.1 & 6.7 & 7.0 & 7.5 & 6.1 & 4.9 & 5.2 & 5.4 & 5.9 \\
\hline & & 4 & 9.4 & 10.3 & 10.6 & 11.8 & 12.4 & 6.7 & 6.4 & 7.1 & 7.5 & 8.1 & 6.6 & 5.3 & 5.5 & 5.6 & 6.4 \\
\hline
\end{tabular}

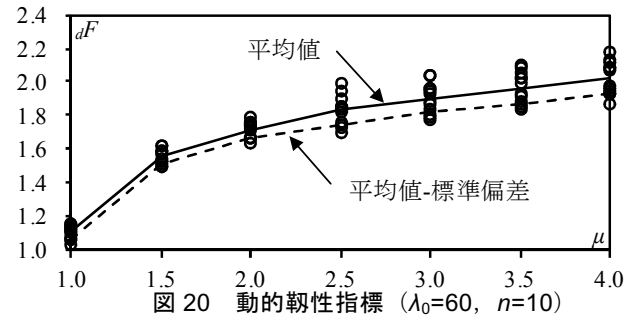

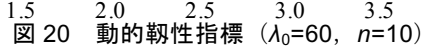

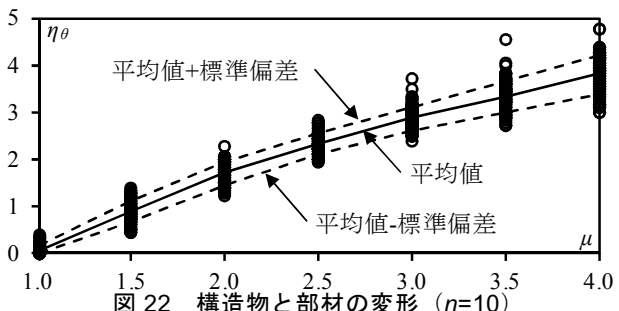

表 5 設計用せん断力係数 $C_{0 S}$

\begin{tabular}{c|c|ccc}
\hline$L[\mathrm{~m}]$ & $n$ & $\phi_{0}=30\left[^{\circ}\right]$ & $\phi_{0}=40\left[^{\circ}\right]$ & $\phi_{0}=50\left[^{\circ}\right]$ \\
\hline \multirow{2}{*}{60} & 10 & 0.197 & 0.195 & 0.191 \\
\cline { 2 - 5 } & 6 & 0.204 & 0.201 & 0.198 \\
\hline \multirow{2}{*}{80} & 10 & 0.197 & 0.195 & 0.191 \\
\cline { 2 - 5 } & 8 & 0.200 & 0.197 & 0.194 \\
\hline 100 & 10 & 0.197 & 0.195 & 0.191 \\
\hline \multirow{2}{*}{120} & 10 & 0.197 & 0.195 & 0.191 \\
\cline { 2 - 5 } & 12 & 0.195 & 0.193 & 0.190 \\
\hline
\end{tabular}
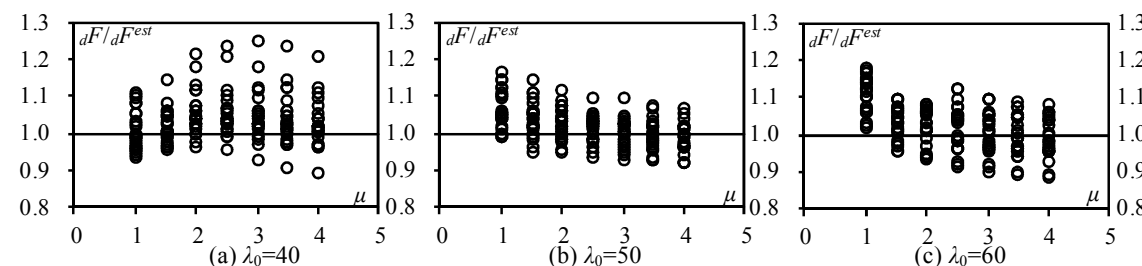

図 21 動的靬性指標の精度の検討

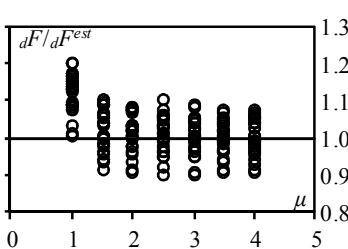

(d) $\stackrel{2}{\lambda_{0}}=70^{3}$

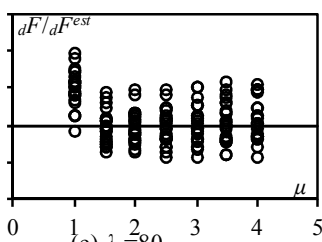


あまり依存せず, 部材細長比 $\lambda_{0}$ と塑性率 $\mu$ の関数で表すことが可能 である. 図 20 より, $\mu=1$ において, ${ }_{d} F$ 值が 1 以上となる結果が存在 するが，これは提案した地震荷重の精度が原因である.

本研究では ${ }_{d} F$ 值の近似式として次式を提案する.

$$
{ }_{d} F^{e s t}=\sqrt{\mu^{q}-1}+1 \quad ; \quad q=1.54 \exp \left[-0.0185 \lambda_{0}\right]
$$

なお，上式は個材座屈の影響を考慮しないよう分割数 $n=10$ の結果 のみから作成し, $\lambda_{0}=50,70$ と $\mu=3.0$ の結果の平均値に合うように作 成している. また, 12 波の入力地震動による応答のばらつきは含め ていない. 解析結果と近似式の比率 $\left({ }_{d} F /{ }_{d} F^{e s t}\right)$ を図 21 に示寸. 図 21 より, 比率は $0.9 \sim 1.2$ 程度となり, 近似值は解析結果と概ね対応 し, 式(33)を用いれば動的勒性指標の近似值を算出できる.

\section{2 構造物と部材の変形}

対象ドームは弾性時には軸力が支配的であり, フープ材によって 初期降伏時の耐力が決定するが, 塑性後は稜線材上の節点が一方向 に漸増し, 部材端で生じる塑性回転角が著しく増加する ${ }^{7)}$. この塑 性回転角はドーム部材の局部座屈などの損傷に寄与寸ると考えられ る. そこで, 本研究では最大鉛直変位からドーム部材の塑性回転角 を簡易に評価できるように, 塑性回転角による変形倍率 $\eta_{\theta}$ と $\mu$ の関 係を検討する. 部材の塑性変形倍率 $\eta_{\theta}$ は次式で与える.

$$
\eta_{\theta}=\theta_{p}{ }^{\max } / \theta_{e} \quad ; \quad \theta_{e}=\left(M_{p} \ell_{0}\right) /(3 E I)=2 \sqrt{2} /(3 \pi) \cdot \varepsilon_{y} \cdot \lambda_{0} \quad \text { (34) }
$$

ここで, $\theta_{p}{ }^{\text {max }}$ は地震応答解析より得られる最大塑性回転角, $\theta_{e}$ は弾 性回転角を表す.なお, 本研究では $\ell_{0}$ を稜線材の 1 部材長さとする.

構造物の塑性率 $\mu$ の関係を図 22 に示寸. 図中の実線は平均值, 破 線は平均值土標準偏差を表す. 図 22 の平均值より, スパン $L$ に対し て 1/300 の変形となる $\mu$ は 2 3 程度となるため, 部材の変形倍率 $\eta_{\theta}$ (各モデルの平均) は 1.7〜2.9 程度となる. 図は省略するが, 僅か ではあるが $\eta_{\theta}$ は分割数 $n$ に依存し, 同じ $\mu$ に対して $n$ が小さいと $\eta_{\theta}$ は小さくなる.なお, 対象ドームの塑性ヒンジ分布を付録 1 に示す.

\section{3 耐震評価方法}

本研究では動的構造耐震指標 ${ }^{23}{ }_{d} I_{S}$ を用いて対象構造物の耐震性 能を判定する. 文献 23)では ${ }_{d} I_{S}$ 值を弾塑性地震応答解析に基づいて 算定されているが，ここではPO 解析から算出する.

PO 解析に基づいて耐震性能を評価する方法を以下に示す.

（1）式(17)，(18)に基づいて地震荷重を作成し，PO 解析を実施し， 初期降伏地震動強さ ${ }_{s} \lambda_{E y}$ を算出する.

（2）限界変形を設定し, 部材細長比 $\lambda_{0}$ に対応する動的勒性指標の 推定值 ${ }_{d} F^{\text {st }}$ を式(33)から算出する.

(3) 得られた ${ }_{d} F^{\text {est }}$ 值に $\lambda_{E y}$ を掛けて, 設定した限界変形に達した時 の地震動強さの推定値 ${ }^{e s t} \lambda_{E}{ }^{\text {cr }}$ を算出する.

(4) 次式が満たされれば, 要求耐震性能を満たすと判断する.

$$
{ }_{d} I_{S}{ }^{e s t} \geq_{d} I_{S O}
$$

ここで, ${ }_{d} I_{S}{ }^{\text {st }}$ 值は PO 解析に基づく動的構造而震指標, ${ }^{2} I_{S O}$ 值 は要求動的構造耐震指標を表し, 次式で与えられる.

$$
{ }_{d} I_{S}{ }^{e s t}=C_{0 S} \cdot{ }^{e s t} \lambda_{E}{ }^{c r},{ }_{d} I_{S O}=C_{0 S} \cdot \lambda_{E O} \quad \text { (36), (37) }
$$

ここで， $C_{0 s}$ は提案する地震荷重（式(18)，(19)）を用いた静的 解析から得られる, $\lambda_{E}=1.0$ に対する層せん断力係数を表す. $\lambda_{E O}$ は要求地震強度指標を表す, $\lambda_{E O}$ は, 実際の設計では, 構造の 使用目的, 経済性, 地震リスク等を総合的に勘案して設定さ れる值と考えられる.

$\lambda_{E O}$ の值として, 告示の極めて稀な地震動を対象とする場合には
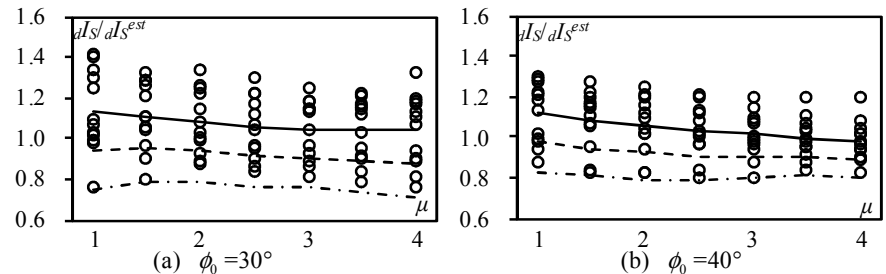

図 23 動的構造耐震指標の精度 $\left(L=100 \mathrm{~m}, \lambda_{0}=60\right)$

5.0 となり，平均的に見れば，表 5 を参照する範囲ではドームの $C_{0 s}$ は 0.2 程度となるため, ${ }_{1} I_{S O}$ は 1.0 程度となる.たとえば, 表 4 より, 設計時に塑性率が 4 以上確保されるようなドームでは，対応する地 震動強さ $\lambda_{E}$ が 5.0 以上となり， $d_{S}$ 值も 1.0 以上となることから高い 耐震性能を有することが確認できる.

式(36)より算出した ${ }_{d}{ }_{S}{ }^{e s t}$ 值と地震応答解析から算出した ${ }_{d} I_{S}$ 值の比 較を図 23 に示寸. 特徵的な 2 例を示寸が, 他のパラメータのドーム もほぼ同様な結果となる。ここで，dIS值は次式で与えられる.

$$
{ }_{d} I_{S}=C_{0 d} \cdot \lambda_{E}{ }^{c r}
$$

ここで, $C_{0 d}$ は図 9 に示される地震応答解析の層せん断力係数, $\lambda_{E}^{c r}$ は時刻歴地震応答解析から直接に得られる限界地震動強さを表す. なお, 図 23 中のプロットは地震動 12 波ごとの結果を含めてあり, 実線は平均值，破線は平均值-標準偏差，一点鎖線は平均值-2×標準 偏差を表す．図 23 より，どちらのモデルも変動係数は $10 \sim 15 \%$ 程 度となり, 地震動によるばらつきが大きい。 また，平均值-標準偏差 は 0.9 程度, 平均值- $2 \times$ 標準偏差は 0.8 程度であり, ${ }_{d} I_{S}$ 值として 12 波の平均值を用いる場合には, 式(36)より得られる ${ }_{d} I_{S}$ est 值を, また, 地震動による変動性を考慮してやや安全側に評価する場合は，式 (36)より得られる ${ }_{d} I_{S}{ }^{e s t}$ 值に安全率として 0.9 もしくは 0.8 程度の値を 乗じた值を採用することとなる.

\section{9. 結論}

本研究ではスパン $L$, 半開角 $\phi_{0}$ および部材細長比 $\lambda_{0}$ をパラメータ として, 周辺をピン支持の単層ラチスドームの地震荷重を提案し, その精度および妥当性について議論した。 また, 静的解析, 地震応 答解析から耐震性能を確認し, その結果をまとめ, 耐震性能評価方 法を提案した. 本研究で対象とした単層ラチスドームに関して得ら れた結論を以下に要約する.

1) 固有振動解析による単層ラチスドームの 1 次固有周期は 0.4 $0.7 \mathrm{sec}$ 程度となり, 加速度応答スペクトル一定領域に位置する。 また，無次元 1 次固有円振動数から周辺ピン支持としたドー ムの 1 次固有周期の推定式を提案した.

2) ドーム最下層の層せん断力を算定するための地震荷重 $F_{H}$, フ 一プ材の軸力を模擬するための地震荷重 $F_{H}+F_{V}$, 稜線材の軸力 を模擬するための地震荷重 $F_{H}-F_{V}$ の 2 種類を提案した. 静的解 析と時刻歴地震応答解析の軸力の比較から, ドーム部材の最 大軸力およびドーム最下層の層せん断力を精度よく評価でき ることを確認した.

3）地震動強さ $\lambda_{E}$ が 1.0 だけでなく 2.5 に対しても精度よく軸力お よび層せん断力を推定できるため, 提案した地震荷重は $\lambda_{E}=2.5$ 相当の地震入力に対しても部材の軸力算定に適用できる. た だし，対象ドームと異なる網目分割によるドームへの適用に ついては今後議論する必要がある.

4) 幾何学的非線形性および材料学的非線形性を考慮した時刻歴 
地震応答解析と PO 解析の結果を比較し, 而荷性能および地震 荷重の適用範囲について分析した。その結果, ドームの半開 角 $\phi_{0}=20^{\circ}$ のモデルの初期降伏地震動は 5.0 以上となり, 高い 耐震性能を有することを確認した， $\phi_{0}=30^{\circ}, 40^{\circ}$ のドームは, 塑性率 2 程度以上確保できれば，また，50॰のドームは塑性率 4 程度が確保できれば, 地震動強さ $\lambda_{E}=5.0$ 以上となることを確 認した。一方, $\phi_{0}=50^{\circ}$ のドームの初期降伏地震動は $1.9 \sim 3.2$ 程度であり, $\phi_{0}=30^{\circ}, 40^{\circ}$ のドームに比べてやや耐震性が低く, 塑性率が 4 以上となる地震動に対する応答性状の分析ととも に, 固定荷重に対する安全率が本研究で設定した值より大き い場合について今後さらに検討が必要であることを確認した．

5) 動的勒性指標 ${ }_{d} F$ と塑性率 $\mu$ の関係を分析した。 その結果, ${ }_{d} F$ 值は部材細長比 $\lambda_{0}$ に依存し, スパン $L$ に対して $1 / 300$ 相当の 鉛直変位が生じた時の ${ }_{d} F$ 值は $\lambda_{0}=40$ で $1.9 \sim 2.1$ 程度, $\lambda_{0}=50$ で $1.8 \sim 2.0$ 程度, $\lambda_{0}=60$ で $1.7 \sim 1.9$ 程度, $\lambda_{0}=70$ で $1.6 \sim 1.8$ 程 度, $\lambda_{0}=80$ で $1.5 \sim 1.7$ 程度となる. また, 塑性率 $\mu$ と部材細長 比 $\lambda_{0}$ を関数とした ${ }_{d} F$ 值の近似式を提案し, その值を用いたド 一ムの耐震性能の評価方法を示した。 この近似式と提案した 地震荷重を用いれば，固定荷重に対して 2 倍程度で設計され たドームの耐震性能を簡易に評価することができる.

本研究では下部構造を RC のような剛と仮定し，境界条件を周辺 ピン支持とした. しかし, 下部構造に支えられた場合, 剛性が低い ため，ピン支持と仮定することは出来ない。したがって，下部構造 がある場合の地震荷重について今後検討が必要である。また，本研 究で提案した地震荷重は入力地震動として告示波と想定しているた め，スペクトル特性が異なる地震動を対象とした場合の適用性につ いても検討する必要がある. なお，本研究ではシェル的な座屈を対 象としたが，個材座屈が生じた場合の動的勒性指標については今後 検討が必要である.

\section{参考文献}

1) 日本建築学会 : ラチスシェルの座屈と耐力，2010

2) 石川浩一郎, 加藤史郎：上下地震動を受ける二層立体ラチスドームの耐 震性に関する研究, 日本建築学会構造系論文報告集, 第 447 号, pp.79-88, 1993.5

3) 熊谷知彦, 谷口与史也, 小河利行, 増山真紀子 : 網目形状の異なる二層 立体ラチスドームの静的および動的弾塑性座屈性状, 日本建築学会構造 系論文集，pp.107-114，2006.12

4) 加藤史郎, 向山洋一, 植木隆司 : 高ライズの単層ラチスドームの地震応 答性状, 日本建築学会構造系論文報告集, 第 442 号, pp.101-109, 1992.12

5) 加藤史郎, 向山洋一：低ライズの単層ラチスドームの地震応答性状, 日 本建築学会構造系論文報告集, 第 488 号, pp.87-96, 1996

6) Xu-Dong Zhi, Feng Fan, Shi-Zhao : Failure Mechanisms of Single-Layer Reticulated Domes Subjected to Earthquakes, Vol. 48, Journal of the IASS, pp.29-44, 2007

7) 中澤祥二, 高橋直生, 加藤史郎：下部構造を有する単層ラチスドームの 耐震性能評価に関する研究，日本建築学会構造系論文集，第 686 号， pp.799-807, 2013.4

8) 日本建築学会 : 空間構造の動的挙動と耐震設計，2006

9) 加藤史郎, 小西克尚, 中澤祥二, 向山洋一, 打越瑞昌: 下部構造に支持 された空間構造の振動解析用質点簡易モデル, 構造工学論文集, Vol.48B, pp.37-47, 2002.3

10）加藤史郎, 小西克尚 : ラチスドームの Push-over analysis に基づく地震応 答推定に関する一考察 1 次モード支配型の空間構造に対する検討，日 本建築学会構造系論文集, 第 561 号, pp.153-160, 2002.11

11) S.Kato, S.Nakazawa, K.Saito : Two-mode Based Estimation of Equivalent Seismic Loads and Static Estimation of Dynamic Response of Reticular Domes supported by Ductile Substructures, Vol. 47, Journal of the IASS, pp.35-52,
2006

12）中澤祥二, 斎藤慶太，加藤史郎：劣化型履歴を有するブレース架構で支 持された複層ラチスドームの地震応答と静的地震荷重の推定, 日本建築 学会構造系論文集，第 608 号，pp.69-76，2006.10

13) 竹内 徹, 小河利行, 中川美香, 熊谷知彦: 応答スペクトル法による中 規模ラチスドームの地震応答評価，日本建築学会構造系論文集，第 579 号, pp.71-78, 2004.5

14）竹内 徹，小河利行，佐藤英佑，中間明子，熊谷知彦：支持架構付きラ チスドームにおける地震応答評価手法の適用範囲, 構造工学論文集, Vol.52B, pp.53-61, 2006.3

15) 植木隆司, 加藤史郎, 向山洋一, 松栄泰男 : 両端に回転ばねのある部材 で構成される単層ラチスドームの弾塑性座屈荷重, 日本建築学会構造系 論文報告集，第 448 号，pp.47-58，1993.6

16）建築物の構造関係技術基準解説書，2007

17) 建設省住宅局建築指導課編集 : 改正建築基準法（2 年目施工）の解説, 新日本法規，2000.6

18）中澤祥二，立道郁生，嶋登志夫，加藤史郎，平野健太：体育館・工場な ど空間構造物の地震リスク評価に関する基礎的研究, 構造工学論文集, Vol.53B, pp.227-237, 2007.3

19）高島英幸，西園博美，加藤史郎：上下地震動を受ける矩形平面状の屋根 型偏平球殼の応答性状，応答值の推定と位相差の影響の検討，日本建築 学会構造系論文報告集, 第 383 号, pp.58-68, 1988.1

20）加藤史郎，庄村昌明，向山洋一：水平と鉛直地震動を受ける大スパン単 層ラチスドームの応答性状と崩壊加速度に関する研究，日本建築学会構 造系論文集，第477 号，pp.87-96，1995.11

21) Shiro Kato and Shoji Nakazawa : Seismic Design Method to Reduce the Responses of Single Layer Reticular Domes by Means of Yielding of Substructure under Severe Earthquake motions, Proceedings of the IASS 2001, Nagoya, 2001

22）笠井和彦，伊藤浩資，渡辺厚：等価線形化法による一質点弾塑性構造の 最大応答予測法，日本建築学会構造系論文集，第 571 号, pp.53-62, 2003.9

23）中澤祥二，柏井恭平，大家貴徳，加藤史郎：エネルギー法に基づく体育 館等の桁面ブレースの動的勒性指標の推定, 日本建築学会構造系論文集, 第 657 号, pp.1983-1990，2010.11

24）加藤史郎, 中澤祥二, 大家貴徳，柏井恭平：弾塑性地震応答解析に基つ く体育館等のブレースの動的勒性指標の検討, 日本建築学会構造系論文 集，第 647 号, pp.129-135, 2010.1

25) 加藤史郎，中澤祥二：下部構造エネルギー吸収型単層ラチスドームの地 震時動的崩壊性状, 日本建築学会構造系論文集, 第 548 号, pp.81-88, 2001.10

\section{付録 1) 塑性ヒンジ分布}

一例ではあるが， $L=100 \mathrm{~m}, \quad \phi_{0}=30^{\circ}, \lambda_{0}=60$ のドームの弾塑性時刻歷地震応 答解析より得られる塑性ヒンジ分布を付図 1 に示寸. 図中の○は塑性ヒンジ, ○は最大鉛直変位となる節点を表す. 地震動強さ $\lambda_{E}$ は表 4 を参考に $9(\mu=1.6)$ と $10(\mu=4.6)$, 入力地震動は El Centro NS 位相の模擬地震動とする. 付図 1 より，最大鉛直変位は第 8 周目の $\mathrm{AOA}^{\prime}$ 線（図 1 参照）上の節点で発生する。 塑性ヒンジは第 8 周目のフープ材と $\mathrm{AOA}^{\prime}$ 線上の稜線材で多く発生し, $\lambda_{E}$ の増 加に伴い, $\mathrm{AOA}^{\prime}$ 線上の稜線材およびその部材に近接したフープ材で塑性ヒン ジが増加する.なお, 本論では省略するが, ドームの半開角 $\phi_{0}$ の増加に伴い, $\mathrm{AOA}^{\prime}$ 線上付近の部材に塑性ヒンジが集中する。また，下部構造を有するドー ムに関しては文献 25)に塑性ヒンジ分布が示されているので参考にされたい

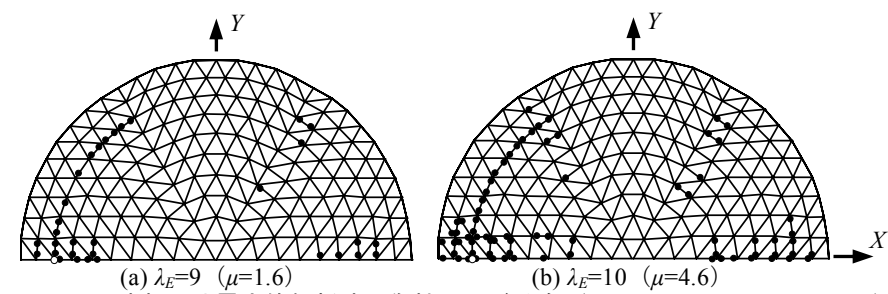
付図 1 時刻歴地震応答解析時の塑性ヒンジ分布 $\left(L=100 \mathrm{~m}, \quad \phi_{0}=30^{\circ}, \lambda_{0}=60\right)$ 注

注 1) 曲げモーメントの精度

紙面の都合上，詳細な説明は省略するが，提案した地震荷重を用いた静 的解析より得られるドーム部材の曲げモーメントは応答解析の結果に比べ て過小評価される。しかし, 図 7 でフープ材は軸力が支配的であり, 図 19 で初期降伏時の耐力を概ね推定できているため，対象ドームでは曲げモー メントの精度は大きく影響されない. 曲げモーメントによって耐力が決ま るドームを対象とした地震荷重については今後の課題とする. 


\title{
SEISMIC LOADS FOR SINGLE LAYER RETICULAR DOMES AND SEISMIC PERFORMANCE EVALUATION
}

\author{
Shoji NAKAZAWA*, Toshimasa YANAGISAWA** and Shiro KATO*** \\ * Prof., Dept. of Arch. and Civil Eng., Toyohashi Univ. of Tech., Dr. Eng. \\ ** Graduate Student, Dept. of Arch. and Civil Eng., Toyohashi Univ. of Tech. \\ *** Prof. Emeritus, Toyohashi Univ. of Tech., Dr. Eng.
}

The present research proposes statically equivalent seismic loads and a method to evaluate seismic performance which can be applied to design of single layer reticular domes. The dome is supported by pins at its circular periphery. The self-weight is assumed $1500 \mathrm{~N} / \mathrm{m}^{2}$ and the members of domes are steel tubular sections and the structural sections are proportioned against two times dead load, however the sections within each dome are assumed identical. The connections of the members are assumed fully rigid. In this study, the analysis parameters are the span $L$, half open angle $\phi_{0}$ and member slenderness ratio $\lambda_{0}$. The values of $L$ is varied from 60 meters to 120 meters, the values of $\phi_{0}$ is varied from 20 degrees to 50 degrees and the values of $\lambda_{0}$ is varied from 40 to 80 .

First, the responses of accelerations and axial forces are evaluated by linear elastic response analysis for the serviceability limit level, and based on the results the magnitudes and distributions of the seismic loads to the dome surface are proposed for their dynamic responses. Input earthquake motions are artificially simulated based on the design acceleration response spectrum given in the Building Standard Code of Japan, corresponding to a soil column of the kind II for ordinary soil condition.

Second the accuracy of this proposed seismic loads are investigated by comparing the axial forces of members under the seismic loads with those obtained by linear elastic response analysis using many simulated design earthquake motions. In the results, the axial forces of dynamic analysis and static analysis show a good correspondence. Therefore, the proposed seismic load is useful when the section areas of the single layer reticular domes are designed for earthquake motions.

Third, the collapse mechanism is discussed based on pushover analysis using the proposed seismic loads but with increased magnitudes for various seismic intensities, followed by comparison of the results with those of elastic-plastic dynamic buckling analysis for severe earthquake motions. In the results, the resistance capacities of the single layer reticular domes are confirmed and the values of dynamic analysis and static analysis show a good correspondence. Therefore, these values can be calculated from static analysis and the proposed seismic load can be used until the initial yield of structures.

Finally, the dynamic ductility indexes of the domes are calculated and the approximation formula is proposed. An effective evaluation method of their seismic performance of the domes is proposed and the fluctuation by an earthquake input was also examined. 